\title{
Aromatase inhibition 2013: clinical state of the art and questions that remain to be solved
}

\author{
Per Eystein Lønning ${ }^{1,2}$ and Hans Petter Eikesdal ${ }^{1,2}$ \\ ${ }^{1}$ Section of Oncology, Department of Clinical Science, University of Bergen, Bergen, Norway \\ ${ }^{2}$ Department of Oncology, Haukeland University Hospital, Jonas Lies vei 26, N-5021 Bergen, Norway
}

Correspondence should be addressed

to P E Lønning

Email

per.lonning@helse-bergen.no

\begin{abstract}
Following their successful implementation for the treatment of metastatic breast cancer, the 'third-generation' aromatase inhibitors (anastrozole, letrozole, and exemestane) have now become standard adjuvant endocrine treatment for postmenopausal estrogen receptor-positive breast cancers. These drugs are characterized by potent aromatase inhibition, causing $>98 \%$ inhibition of estrogen synthesis in vivo. A recent meta-analysis found no difference in anti-tumor efficacy between these three compounds. As of today, aromatase inhibitor monotherapy and sequential treatment using tamoxifen followed by an aromatase inhibitor for a total of 5 years are considered equipotent treatment options. However, current trials are addressing the potential benefit of extending treatment duration beyond 5 years. Regarding side effects, aromatase inhibitors are not found associated with enhanced risk of cardiovascular disease, and enhanced bone loss is prevented by adding bisphosphonates in concert for those at danger of developing osteoporosis. However, arthralgia and carpal tunnel syndrome preclude drug administration among a few patients. While recent findings have questioned the use of aromatase inhibitors among overweight and, in particular, obese patients, this problem seems to focus on premenopausal patients treated with an aromatase inhibitor and an LH-RH analog in concert, questioning the efficacy of LH-RH analogs rather than aromatase inhibitors among overweight patients. Finally, recent findings revealing a benefit from adding the mTOR inhibitor everolimus to endocrine treatment indicate targeted therapy against defined growth factor pathways to be a way forward, by reversing acquired resistance to endocrine therapy.
\end{abstract}
Key Words
- breast cancer
- endocrine therapy
- aromatase inhibitors
- adjuvant therapy
- resistance

Endocrine-Related Cancer (2013) 20, R183-R201

\section{Introduction}

The history of endocrine therapy for advanced breast cancer started more than a decade ago with the seminal discovery by George Beatson (1896) that ovarian ablation may cause tumor regression in premenopausal women. While ovarian estrogen synthesis ceases at the menopause, postmenopausal women still have plasma estrogen levels present at low concentration. Previously believed to occur by adrenal glandular synthesis, it later became clear that the adrenals are contributors of circulating androgens, subsequently converted into estrogens in different body compartments (Lønning et al. 1990). The idea that estrogen ablation might also work in postmenopausal women triggered implementation of adrenalectomy as well as hypophysectomy in the 1950s (Luft et al. 1952, Huggins \& Dao 1953, Fracchia et al. 1967, 1971). 
The fact that adrenalectomy as well as hypophysectomy was an effective antitumor therapy albeit at a cost of high morbidity motivated trials on 'medical adrenalectomy', leading to testing of glucocorticoids (Kofman et al. 1958, Lemon 1959), as well as adrenal enzyme inhibitors like ketoconazole (Harris et al. 1988). While the response to these drugs was inferior to surgical adrenalectomy/ hypophysectomy, these attempts, by chance, paved the way for aminoglutethimide, subsequently leading to implementation of aromatase inhibition for breast cancer therapy.

The details of how aminoglutethimide was introduced for breast cancer therapy has been outlined elsewhere (Lønning \& Kvinnsland 1988). It was originally developed as an unsuccessful antiepileptic compound causing significant adrenocortical toxicity. Following an initial clinical observation revealing efficacy of aminoglutethimide in a breast cancer patient by Ralph Cash et al. (1967), Richard Santen et al. (1974) systematically implemented aminoglutethimide in concert with glucocorticoid substitution in an attempt to achieve an effective medical adrenalectomy. Their studies demonstrated clinical efficacy of aminoglutethimide for the treatment of postmenopausal breast cancer (Santen et al. 1981). In addition, their systematic endocrine studies revealed surprising findings with respect to its mechanism of action. Contrary to expectations, they found adrenal androgen synthesis to be preserved (Samojlik et al. 1980) despite profound suppression of plasma estrogen levels (Santen 1981). Thus, in a seminal study, they confirmed aminoglutethimide to act as an aromatase inhibitor in vivo (Santen et al. 1978), introducing aromatase inhibition as a novel concept in breast cancer therapy. Studies conducted several years later revealed aminoglutethimide, in addition, to enhance estrogen metabolism (Lønning et al. 1987, 1989a).

In parallel, Harry and Angela Brodie experimentally worked on androstenedione derivatives for aromatase inhibition (Brodie et al. 1977, 1983), leading to the first pilot trial revealing anti-tumor efficacy of 4-hydroxyandrostenedione in metastatic breast cancer (Coombes et al. 1984).

Following development of aminoglutethimide and 4-hydroxyandrostenedione (known as lentaron), other so-called second-generation aromatase inhibitors, including fadrozole, were developed; for a detailed review of clinical studies evaluating first- and second-generation aromatase inhibitors for metastatic breast cancer, the readers are referred to a previous review (Lønning 2004). None of these compounds are in clinical use any longer. In brief, while some of these compounds, like fadrozole and 4-hydroxyandrostenedione, were associated with less side effects compared with standard treatment regimens at that time, anti-tumor effects were not superior to the effect of aminoglutethimide or other contemporary regimens like tamoxifen and progestins administered at high pharmacological doses (see Lønning (2004) for references). However, the lessons learned from the clinical use of these compounds, in concert with translational research evaluating their endocrine effects, provide important information to our understanding of key principles related to treatment with aromatase inhibitors.

\section{Endocrine principles of aromatase inhibition}

In postmenopausal women, estrogens are synthesized in most of the body compartments, including the liver, muscle, connective tissue, and skin (Geisler \& Lønning 2005). While one single aromatase gene exists, the gene contains at least ten different promoters (Bulun et al. 2003), with different promoters and ligands regulating estrogen synthesis across different tissue types (Agarwal et al. 1996, Clyne et al. 2004, Mendelson et al. 2005, Zhou et al. 2005). Notably, these promoters play a different role in benign vs malignant breast tissue; although the 1.4 promoter is the main activator in normal breast tissue, promoters II, 1.3, and 1.7 have been shown to play a role in addition to 1.4 in breast cancer tissue (Bulun et al. 2003). However, proteins coded for by the different promoters are similar. The aromatase is able to convert testosterone into estradiol $\left(\mathrm{E}_{2}\right)$ and androstenedione into estrone $\left(\mathrm{E}_{1}\right)$. While circulating androstenedione as well as testosterone in postmenopausal women is considered of adrenal origin, the ovary seems to provide a minor, albeit significant, contribution of circulating testosterone (Dowsett et al. 1988, Sluijmer et al. 1995, Couzinet et al. 2001). These circulating androgens are taken up by the different tissue compartments for subsequent aromatization.

Circulating androstenedione levels $(4-5 \mathrm{nM})$ exceed the circulating levels of testosterone $(0.5-1 \mathrm{nM})$ by a factor of about 5-10 (Geisler et al. 1995); in addition, the aromatase enzyme has a four- to fivefold higher affinity for androstenedione compared with testosterone (Lønning et al. 1990). Thus, aromatization of androstenedione into $E_{1}$ is the major pathway of estrogen synthesis in postmenopausal women. While $\mathrm{E}_{1}$ is inactive by itself with respect to stimulating estrogen receptor activation, it is easily converted to $\mathrm{E}_{2}$ by multiple dehydrogenases (Haynes et al. 2010).

Considering plasma estrogen levels in postmenopausal women, plasma $\mathrm{E}_{1}(50-70 \mathrm{pM})$ exceeds $\mathrm{E}_{2}(12-20 \mathrm{pM})$

Published by Bioscientifica Ltd. 
concentrations by a factor of 4-5. In addition, postmenopausal women reveal plasma concentrations of $E_{1}$ sulfate $\left(\mathrm{E}_{1} \mathrm{~S}\right)$ of about 4-600 pM (Geisler et al. 2008b, Lønning et al. 2009). To be biologically active, $\mathrm{E}_{1} \mathrm{~S}$ has to be deconjugated prior to conversion into $\mathrm{E}_{2}$.

\section{Measuring in vivo aromatase inhibition}

A major problem in evaluating the biochemical efficacy of aromatase inhibitors in vivo relates to technical difficulties measuring estrogen concentrations in the low concentration range. To achieve robust methods to assess in vivo aromatase inhibition and compare efficacy of different aromatase inhibitors, in collaboration with Mitch Dowsett's group, we developed a sensitive method for in vivo aromatization assessment based on combined ${ }^{3} \mathrm{H}$-androstenedione and ${ }^{14} \mathrm{C}-\mathrm{E}_{1}$ injections, followed by measurement of the isotope ratio in urinary estrogen metabolites (Lønning et al. 1989b, Jacobs et al. 1991). A formal assessment of this method revealed a sensitivity indicating an ability to detect aromatase inhibition of $>99.1 \%$ in the majority of patients (Dowsett et al. 1995).

Using this method, we systematically classified different aromatase inhibitors (Jones et al. 1992, Lønning et al. 1991, MacNeill et al. 1992, 1994, 1995, Geisler et al. $1996 b, 1998,2002)$ based on their efficacy in inhibiting total body in vivo aromatization (Table 1). The findings

Table 1 Maximum inhibition of total body aromatization obtained with previously and currently used aromatase inhibitors.

\begin{tabular}{|c|c|c|c|}
\hline & Generation & $\begin{array}{c}\text { Maximum } \\
\text { inhibition (\%) }\end{array}$ & References \\
\hline Rogletimide & First & 74 & $\begin{array}{l}\text { MacNeill et al. } \\
\text { (1992) }\end{array}$ \\
\hline Aminoglutethimide & First & 91 & $\begin{array}{l}\text { MacNeill et al. } \\
\text { (1992) }\end{array}$ \\
\hline $\begin{array}{l}\text { Aminoglutethimide } \\
+ \text { formestane }\end{array}$ & $\begin{array}{l}\text { First/ } \\
\text { second }\end{array}$ & 94 & $\begin{array}{l}\text { MacNeill et al. } \\
\text { (1994) }\end{array}$ \\
\hline Formestane (oral) & Second & 70 & $\begin{array}{l}\text { MacNeill et al. } \\
\text { (1995) }\end{array}$ \\
\hline Fadrozole & Second & 93 & $\begin{array}{l}\text { Lønning et al. } \\
\qquad(1991)\end{array}$ \\
\hline Formestane (i.m.) & Second & 92 & $\begin{array}{l}\text { Jones et al. } \\
\text { (1992) }\end{array}$ \\
\hline Letrozole & Third & 99.1 & $\begin{array}{l}\text { Dowsett et al. } \\
\text { (1995) and } \\
\text { Geisler et al. } \\
(2002)\end{array}$ \\
\hline Anastrozole & Third & 98.1 & $\begin{array}{l}\text { Geisler et al. } \\
\quad(1996 b, 2002)\end{array}$ \\
\hline Exemestane & Third & 97.9 & $\begin{array}{l}\text { Geisler et al. } \\
\text { (1998) }\end{array}$ \\
\hline
\end{tabular}

provide three key messages; first, while it has been unclear whether the three-dimensional structure of the aromatase protein allows combined binding of a non-steroidal and a steroidal (4-hydroxyandrostenedione or exemestane) substrate-pocket binding compound, we found that adding aminoglutethimide to 4-hydroxyestrone enhanced aromatase inhibition, a finding consistent with data on plasma estrogen values with the same combined regimen (Geisler et al. 1996a). Secondly, there is a difference between 'third-generation' aromatase inhibitors and previous compounds regarding in vivo efficacy. Notably, each of the three so-called third-generation inhibitors in current use for breast cancer treatment (exemestane, anastrozole, and letrozole) causes on average $>98 \%$ inhibition in individual patients. In contrast, the firstand second-generation inhibitors cause aromatase inhibition of $<90 \%$. Thirdly, this difference seems to be translated into clinically meaningful effects, as the third-generation inhibitors, in contrast to the first/ second-generation compounds, have revealed clinical superiority compared with other endocrine treatment regimens (see below).

\section{Evaluating plasma estrogen levels in patients on treatment with aromatase inhibitors}

While in vivo tracer injections provide the 'gold standard' when measuring in vivo aromatization and the endocrine efficacy of different aromatase inhibitors, the method is time- and source-consuming and may be applied on a limited number of patients for research purposes only. It may sometimes be necessary to determine on-treatment plasma estrogen levels in relation to treatment with different aromatase inhibitors as part of quality control.

While in vivo tracer studies indicate that thirdgeneration aromatase inhibitors may inhibit total body estrogen synthesis by $>98 \%$, there are several studies reporting plasma estrogen levels to be sustained at 20-40\% of pretreatment levels on therapy. As for most of these studies, clearly the assays applied did not have the sensitivity required for such a low concentration analysis. Taking normal plasma levels of $\mathrm{E}_{1}$ and $\mathrm{E}_{2}$ into account, assays with a sensitivity limit of 5-7 and 1-2 pM respectively is needed to detect $>90 \%$ suppression of plasma hormone levels during treatment with an aromatase inhibitor. In addition, for steroidal compounds like exemestane, there may be cross-contamination by the drug itself or some of its metabolites, requesting preanalytical sample purification by chromatographic methods (Johannessen et al. 1997). Misinterpretations

Published by Bioscientifica Ltd. 
due to technical problems carry a potential hazard; one example includes the use of local estrogen application for gynecological complications. Such local application leads to a modest but significant increase in plasma estrogen levels (Kendall et al. 2006, Wills et al. 2012) that may easily be overlooked with the use of less sensitive analytical methods, leading to potential erroneous conclusions regarding its safety in patients on treatment with an aromatase inhibitor.

Notably, while there is no international standardization regarding measurement of estrogens in the low concentration range, a few laboratories around the world over the years have put much effort into developing highly sensitive and specific assays for that purpose. Thus, the group headed by Mitch Dowsett in London (Dowsett et al. 1987, Dixon et al. 2008) as well as our own group (Lønning \& Ekse 1995, Geisler et al. 2008a) have developed such highly sensitive assays. Using these methods, we detected plasma estrogen suppression of $>90 \%$ with the third-generation aromatase inhibitors (Geisler et al. 1996b, 2008b, Dixon et al. 2008), a finding consistent with the results obtained from tracer studies.

\section{Normal breast tissue and intratumor estrogen levels}

It has been challenged to what extent findings related to plasma estrogen suppression and total body aromatization may reflect alterations at the tumor tissue level. There are two main reasons for such concerns: first, it has been known for decades that estrogen levels are higher in tissue compared with plasma (van Landeghem et al. 1985). Secondly, immunostaining has revealed aromatase protein expression in breast cancer tissue (Sasano et al. 2005).

If the estrogen levels are elevated in normal as well as cancerous breast tissue due to local synthesis of estrogen, this would have significant implications in breast cancer prevention as well as therapy. First, it opens the possibility that for some tumors, lack of response could be due to inefficient tissue estrogen suppression, not detected by total body tracer studies or plasma estrogen measurement. Secondly, the fact that local aromatization is regulated by tissue-specific promoters and ligands raises the possibility of 'targeted' or local estrogen synthesis inhibition (Fig. 1). Such therapeutic or preventive strategies may offer great advantages, omitting unwanted side effects from systemic estrogen deprivation.

To address the topic of local estrogen production, we measured the levels of breast cancer, normal tissue, and

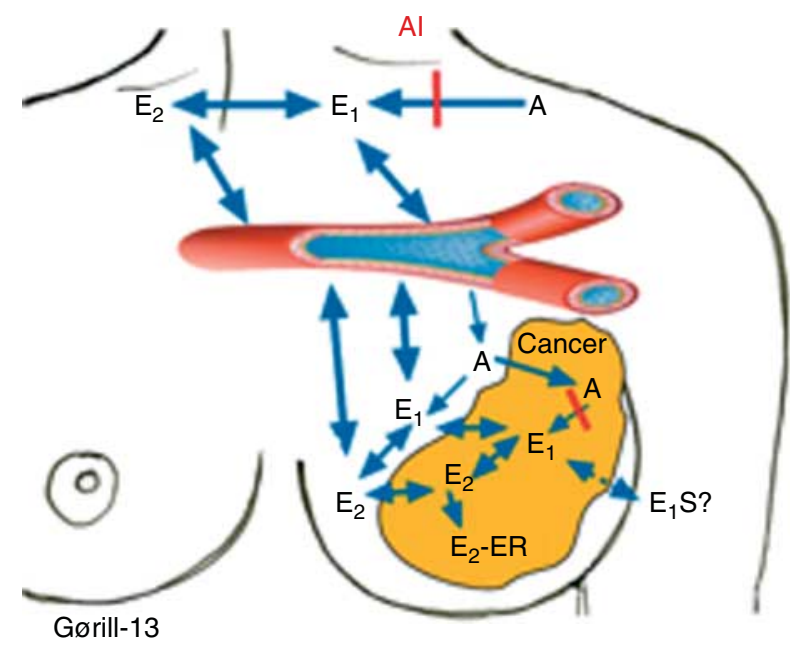

Figure 1

Local vs total body aromatization as a source for estrogen. There is an extensive exchange of estrone $\left(E_{1}\right)$ and estradiol $\left(E_{2}\right)$ between the plasma and the breast and breast cancer tissue due to total body aromatization, which overrules the local aromatization in the breast. Local administration of an aromatase inhibitor is therefore not a rational strategy.

$A$, androstenedione; $E_{2}-E R$, estradiol bound to estrogen receptor; $E_{1} S_{\text {, estrone sulfate. }}$

plasma estrogens, and correlated hormone levels with the expression of hormone-modulating enzymes, including the different steroid dehydrogenases as well as aromatase and sulphokinase/sulphatase levels (Lønning et al. 2009, Haynes et al. 2010). The results have been discussed in detail elsewhere (Lønning et al. 2011). In brief, no correlation between intratumor estrogen levels and intratumor aromatase expression levels was found. Rather, normal breast and breast cancer tissue estrogen levels in general reflect plasma estrogen levels due to rapid equilibrium between the compartments (Fig. 1). The reason why tissue $E_{2}$ and $E_{1}$ levels exceed plasma concentration probably reflects the lipophilicity of these compounds; in contrast, plasma levels of $\mathrm{E}_{1} \mathrm{~S}$ exceeds tissue concentration. In addition, there seems to be an intra-tumor conversion of $\mathrm{E}_{1}$ into $\mathrm{E}_{2}$ by local dehydrogenases. Finally, a significant amount of elevated intratumor $\mathrm{E}_{2}$ reflects an intratumor pool of estrogen receptor-bound hormone.

Consistent with these findings, studies by William Miller et al. (1998) in Edinburgh as well as our own team (Geisler et al. 2001, 2008b) have documented third-generation compounds like anastrozole and letrozole to consistently suppress intratumor estrogen levels as well. So far, there is no evidence indicating that local tumor estrogen synthesis may be a cause of therapy failure in patients on treatment with a third-generation aromatase inhibitor.

Published by Bioscientifica Ltd. 
Table 2 Results of the major adjuvant studies comparing third-generation aromatase inhibitors and tamoxifen.

\begin{tabular}{|c|c|c|c|c|c|}
\hline \multirow[b]{2}{*}{ No. of patients } & \multirow[b]{2}{*}{ Drug } & \multicolumn{2}{|c|}{ Survival } & \multirow[b]{2}{*}{ Follow-up } & \multirow[b]{2}{*}{ References } \\
\hline & & DFS & os & & \\
\hline \multicolumn{6}{|l|}{ ATAC } \\
\hline 3116 & $\mathrm{~T}$ & $0.90^{\mathrm{a}}$ & 0.97 & 100 months & Forbes et al. (2008) \\
\hline 3125 & $A$ & & & & \\
\hline 3125 & $\mathrm{~T} \rightarrow \mathrm{A}^{\mathrm{b}}$ & & & & \\
\hline \multicolumn{6}{|l|}{ BIG 1-98 } \\
\hline 2459 & $\mathrm{~T}$ & $0.86^{\mathrm{a}}$ & $0.87^{a}$ & 8.1 years & Regan et al. (2011) \\
\hline 2463 & $\mathrm{~L}$ & & & & \\
\hline 1545 & $\mathrm{~L} \rightarrow \mathrm{T}$ & $1.06^{c}$ & $0.97^{d}$ & & \\
\hline 1548 & $\mathrm{~T} \rightarrow \mathrm{L}$ & $1.07^{c}$ & $1.10^{d}$ & & \\
\hline \multicolumn{6}{|l|}{ ABCSG-8 } \\
\hline 1849 & $\mathrm{~T}$ & $0.80^{d}$ & $0.87^{d}$ & 60 months & Dubsky et al. (2012) \\
\hline 1865 & $\mathrm{~T} \rightarrow \mathrm{A}$ & & & & \\
\hline \multicolumn{6}{|l|}{ ARNO 95} \\
\hline 490 & $\mathrm{~T}$ & $0.66^{\mathrm{e}}$ & $0.53^{\mathrm{e}}$ & 30.1 months & Kaufmann et al. (2007) \\
\hline 489 & $\mathrm{~T} \rightarrow \mathrm{A}$ & & & & \\
\hline \multicolumn{6}{|l|}{ ITA } \\
\hline 225 & $\mathrm{~T}$ & $0.64^{\mathrm{e}}$ & $0.79^{d}$ & 128 months & Boccardo et al. (2013) \\
\hline 223 & $\mathrm{~T} \rightarrow \mathrm{A}$ & & & & \\
\hline \multicolumn{6}{|l|}{ IES } \\
\hline 2305 & $\mathrm{~T}$ & $0.81^{\mathrm{e}}$ & $0.86^{\mathrm{e}}$ & 91 months & Bliss et al. (2012) \\
\hline 2294 & $\mathrm{~T} \rightarrow \mathrm{E}$ & & & & \\
\hline \multicolumn{6}{|l|}{ TEAM } \\
\hline 4868 & $\mathrm{~T} \rightarrow \mathrm{E}$ & $0.97^{d}$ & $1.00^{d}$ & 5.1 years & van de Velde et al. (2011) \\
\hline 4898 & $\mathrm{E}$ & & & & \\
\hline
\end{tabular}

\section{Aromatase inhibitors in the adjuvant setting}

The findings from major studies comparing thirdgeneration aromatase inhibitors with tamoxifen for adjuvant treatment (Kaufmann et al. 2007, Forbes et al. 2008, Regan et al. 2011, van de Velde et al. 2011, Bliss et al. 2012, Dubsky et al. 2012, Boccardo et al. 2013) are summarized in Table 2. These studies evaluated two treatment approaches, aromatase inhibitor monotherapy or sequential treatment, where 2-3 years of tamoxifen is followed by an aromatase inhibitor. In addition, one study (BIG 1-98) also included a fourth arm; patients randomized to 2 years of letrozole, followed by 3 years with tamoxifen (Mouridsen et al. 2009). The rationale for the sequential approach was based on the findings from studies in the metastatic setting, revealing lack of crossresistance between tamoxifen and aromatase inhibitors; thus, the idea was that switching from tamoxifen to an aromatase inhibitor during 5 years of adjuvant therapy may prevent acquired resistance from developing. Notably, a combined meta-analysis of these data
(Dowsett et al. 2010) did not reveal superiority for any of the three compounds (anastrozole, letrozole, or exemestane) compared with any of the two others. The key findings, based on this meta-analysis, are summarized in the following.

Regarding the two major strategies (aromatase inhibitor monotherapy for 5 years after surgery, alternatively, tamoxifen for 2-3 years to be followed by an aromatase inhibitor for 3-2 years for a total duration of 5 years), each strategy revealed superiority compared with tamoxifen monotherapy in preventing recurrence. Among 9856 patients allocated to monotherapy with either tamoxifen or an aromatase inhibitor, following a mean duration of follow-up of 5.8 years, aromatase inhibitor monotherapy decreased relapse rate from $12.6 \%$ (for tamoxifen) to $9.6 \%$ with an aromatase inhibitor. As for survival, there was a non-significant improvement related to aromatase inhibition, but the follow-up is still too short to fully assess this end-point. Taking sequential treatment, analyzing patients from the time of randomization between continuing tamoxifen and switching to an

Published by Bioscientifica Ltd. 
aromatase inhibitor, the recurrence rate was reduced from 8.1 to $5 \%$ at 3 years of follow-up from randomization with a significant $0.7 \%$ reduction in breast cancer mortality among those patients receiving an aromatase inhibitor.

Based on the studies presented, aromatase inhibitors have now become standard adjuvant endocrine therapy for postmenopausal breast cancer patients. However, the data summarized above raised the question of whether aromatase inhibitor monotherapy, or sequential treatment, is the optimal strategy. In the four-arm BIG 1-98 study (Table 2), 1548 patients were randomized to tamoxifen for 2 years followed by letrozole for 3 years while 2563 patients had letrozole monotherapy (Mouridsen et al. 2009). At a median follow-up of 71 months from randomization, disease-free as well as overall survival were non-significantly inferior in the crossover compared with the monotherapy arm (hazard ratio (HR) of 1.05 and 1.13 respectively). Interestingly, a benefit was observed among node-positive but not among node-negative patients. In the TEAM study, tamoxifen for 2.5-3 years followed by exemestane for a total treatment duration of 5 years was compared with exemestane monotherapy (van de Velde et al. 2011). With a total of 9766 patients analyzed on an intention-to-treat basis and with a median follow-up of 5.1 years, no difference in disease-free survival between patients in the two arms was recorded.

As for the BIG 1-98 study, another interesting comparison was made between patients treated with letrozole upfront for 2 years followed by tamoxifen for 3 years $(n=1540)$ vs letrozole monotherapy $(n=1546)$. Here again, no difference in outcome between patients in the two treatment arms was recorded.

Taken together, this evidence advocates the use of aromatase inhibitors in the adjuvant treatment of postmenopausal women. However, so far, there are no strong scientific arguments in favor of either sequential or monotherapy compared with the alternative treatment strategy. Considering the cost per quality-adjusted life year gained related to each strategy, notably this depends on the relapse risk but, in addition, patient age at diagnosis (Lønning 2006).

\section{Duration of adjuvant therapy}

While several studies have reported no additional benefit from extending tamoxifen adjuvant therapy beyond 5 years (Fisher et al. 1996, Tormey et al. 1996, Stewart et al. 2001), recent data from the large ATLAS study (Davies et al. 2012) found 10 years of tamoxifen treatment to be superior compared with 5 years of therapy. Most interestingly, while the relative ratio of recurrence was 0.90 between the two treatment arms between 5 and 9 years from diagnosis, it dropped to 0.75 after $10+$ years. The fact that the benefit was delayed may explain why it was overlooked in previous studies. Furthermore, it emphasizes the importance of long-term follow-up in studies evaluating benefit from endocrine treatment.

Notably, three phase III studies have evaluated the effect of adding an aromatase inhibitor following 5 years of tamoxifen. In the MA.17 trial, patients completing 5 years of tamoxifen treatment were randomized to letrozole vs placebo (Goss et al. 2005); the study had to be terminated early (median follow-up of 30 months) and the patients were unblinded to treatment arm due to the extent of benefit (HR for relapse reduced to 0.58 by letrozole treatment). The results further lead to the termination of the NSABP B-33 trial (Mamounas et al. 2008) comparing exemestane with placebo, with a median follow-up time of 30 months, where a HR in favor of exemestane treatment of 0.68 was recorded. However, the effect was not statistically significant $(P=0.07)$ due to the limited number of patients $(n=1598)$ enrolled prior to early termination. Finally, the open-labeled Austrian ABCSG-6a evaluated the benefit of adding anastrozole for 3 years following 5 years of tamoxifen. At a median follow-up of 62.3 months, a benefit for extended therapy with the aromatase inhibitor was recorded (Jakesz et al. 2007).

While today current practice implements the use of aromatase inhibitors at an early stage during the sequence (upfront or after 2-3 years), the results from the ATLAS trial, together with the findings from studies on the extended use of aromatase inhibitors, challenge the concept of 5 years on endocrine therapy as the optimal duration. Currently, there are several studies comparing extended vs 5 years of endocrine therapy with aromatase inhibitor regimens (Table 3).

\section{Aromatase inhibitors in the neoadjuvant setting}

Pre-surgical systemic therapy offers the benefit of downstaging tumors to allow more limited surgery (Dixon $\mathrm{et}$ al. 2009). In addition, it offers a unique setting to evaluate potential predictive factors (Lønning 2003) as well as changes in molecular parameters (Miller et al. 2009, Lønning \& Knappskog 2013) in response to drug therapy. Several studies (Eiermann et al. 2001, Semiglazov et al. 2005, Smith et al. 2005, Cataliotti et al. 2006) have compared third-generation aromatase inhibitors to

Published by Bioscientifica Ltc. 
Table 3 Ongoing studies comparing extended vs 5 years of endocrine therapy with aromatase inhibitor regimens.

\begin{tabular}{|c|c|c|c|c|c|c|}
\hline & No. of patients & Years 1-5 & Years 5-10 & Years 10-15 & Results expected & ClinicalTrials.gov \\
\hline MA.17 extension trial & 1918 & $\mathrm{~T}$ & L or placebo & L or placebo ${ }^{a}$ & 2015 & NCT00754845 \\
\hline NSABP B-42 & 3966 & $\mathrm{Al}$ or $\mathrm{T} \rightarrow \mathrm{Al}$ & L or placebo & - & 2015 & NCT00382070 \\
\hline
\end{tabular}

${ }^{a}$ The study compares an additional 5 years of letrozole/placebo after completing 5 years of tamoxifen and 5 years of letrozole for patients in the original MA.17 study, or letrozole/placebo years 5-10 for patients that previously got an aromatase inhibitor years 1-5.

tamoxifen as primary medical therapy. Whereas letrozole (Eiermann et al. 2001) revealed superiority over tamoxifen, no statistically significant benefit of anastrozole compared with tamoxifen was observed in the two trials performed with this compound (Smith et al. 2005, Cataliotti et al. 2006). Regarding exemestane, one study revealed a benefit in response rate compared with tamoxifen (Semiglazov et al. 2005), but the number of patients was too small for statistical comparison.

During the last few years, the proliferation marker Ki67 has become an important surrogate marker for response to endocrine therapy in the neoadjuvant setting. Comparing the percentage of $\mathrm{Ki}^{+}$proliferating cells before and after 2 weeks of endocrine therapy will indicate those patients with ER + breast cancer that are likely to respond with tumor regression and furthermore predict their long-term outcome (Dowsett et al. 2005, 2007). Patients with a substantial drop in Ki67 have been shown repeatedly to achieve the best response to such treatment (Dowsett et al. 2011a). A further benefit of Ki67 measurement is the early identification of patients with treatment failure, as increasing Ki67 will later translate into clinical tumor progression (Dowsett et al. 2011b). In the PeriOperative Endocrine Therapy for Individualizing Care (POETIC) trial, this knowledge is expanded upon where patients with primary breast cancer are biopsied before and after 2 weeks on either a non-steroidal aromatase inhibitor or no treatment to identify novel biomarkers for response (Dowsett et al. 2011b).

\section{Aromatase inhibitors in metastatic disease}

The role of aromatase inhibitors in metastatic disease has been reviewed elsewhere (Lønning 2004). However, the picture has changed in recent years, since today most patients with metastatic, ER-positive breast cancer have already experienced progression on adjuvant aromatase inhibition.

While previous studies revealed the superiority of aromatase inhibitors compared with tamoxifen (Mouridsen et al. 2001), the fact that most patients with
$\mathrm{ER}+$ tumors that relapse today have received an aromatase inhibitor for adjuvant therapy changes the scenario. As for patients relapsing say $>1$ year following termination of adjuvant therapy, re-implementation of the aromatase inhibitor may be a reasonable choice. In contrast, patients relapsing on treatment or shortly after terminating adjuvant therapy need alternative treatment options. Note that tamoxifen (Mouridsen et al. 2003) as well as fulvestrant (Chia et al. 2008) may have antitumor effects in patients where aromatase inhibitors fail, and the steroidal compound exemestane has been shown effective among patients becoming resistant to a non-steroidal aromatase inhibitor (Lønning et al. 2000). Interestingly, a randomized trial demonstrated a similar efficacy of fulvestrant and exemestane among patients where anastrozole or letrozole fail (Chia et al. 2008). Notably, most previous studies (Howell et al. 2002, 2004, Osborne et al. 2002) administered fulvestrant at a dose of $250 \mathrm{mg}$ injections. While a later study revealed benefit from fulvestrant $500 \mathrm{mg}$ injections compared with anastrozole in first line (Robertson et al. 2012), the data on fulvestrant $500 \mathrm{mg}$ are not ample. Therefore, the data are insufficient to conclude that fulvestrant is superior to aromatase inhibitors, both in the first- and second-line setting. However, fulvestrant is generally well tolerated in this patient population, and the adherence to therapy is ensured by the depot i.m. injections in patients where poor compliance could be a problem.

Currently, there is no general consensus regarding optimal sequencing of endocrine therapy for metastatic breast cancer. However, for patients with metastatic ER+ breast cancer, it remains important to extend endocrine treatment for as long as their disease responds, prior to implementing chemotherapy.

\section{Side effects of aromatase inhibitors}

Estrogens play a key role in many physiological processes other than reproduction. Thus, aromatase knock-out mice reveal multiple metabolic defects (Jones et al. 2001), and aromatase deficiency due to germline mutations causes

Published by Bioscientifica Ltd. 
osteopenia as well as metabolic disturbances in both genders (Morishima et al. 1995, Rochira \& Carani 2009). Thus, a major concern with respect to aromatase inhibition in early breast cancer has been the enhanced bone loss as well as disturbances in lipid metabolism, which could increase the risk of cardiovascular diseases.

Osteoporosis is a major health threat to the aging female population in most countries. Osteoporotic fractures are associated with a significant morbidity and excess mortality (Johnell et al. 2004). The lifetime risk for a hip fracture among European and USA Caucasian females is in the range of $15-20 \%$. In some countries, like in Scandinavia, it may exceed 25\% (Kanis et al. 2002). It is now well established that all aromatase inhibitors moderately enhance bone loss. However, most studies have addressed the effect of aromatase inhibitors on bone loss in phase III studies comparing efficacy and side effects to tamoxifen (Coleman et al. 2007, Eastell et al. 2008), the second expressing anabolic effects on bone metabolism in postmenopausal women (Powles et al. 1996). The effects of exemestane (Lønning et al. 2005) as well as letrozole (Perez et al. 2006), however, on bone metabolism have also been compared with placebo, revealing a moderate loss in bone density. Notably, while ongoing treatment with an aromatase inhibitor is associated with increased bone fracture rate (Coates et al. 2007, Coombes et al. 2007, Eastell et al. 2008) in comparison with tamoxifen, any detrimental effects of aromatase inhibitors on bone metabolism disappear upon terminating the drug (Geisler et al. 2006, Eastell et al. 2008). With the encouraging results from the Austrian Breast Cancer Group, revealing that zoledronic acid may completely prevent aggravated bone loss, even among premenopausal women exposed to ovarian ablation and anastrozole in concert (Gnant et al. 2008), detrimental effects on bone metabolism may be fully preventable.

Another major concern has been with respect to detrimental effects of estrogen suppression on lipid metabolism (Engan et al. 1995) and homocysteine levels (Anker et al. 1995) that could lead to an increased risk of cardiovascular disease. As for the latter, contrary to previous claims, recent evidence suggest that plasma homocysteine may not be a major risk factor with respect to cardiovascular disease after all (Bonaa et al. 2006). For decades, estrogen replacement therapy was believed to protect against cardiovascular events in postmenopausal women. However, while hormone replacement therapy slightly elevates HDL-cholesterol levels, this effect seems not to translate into a reduced risk of cardiovascular disease (Trial 1995, Hulley et al. 1998, Alexander et al. 2001,
Manson et al. 2003, Anderson et al. 2004). Considering the effects of aromatase inhibitors on plasma lipid levels, studies conducted on non-fasting subjects as well as studies on patients with metastatic disease, often suffering from metabolic disturbances, are subject to multiple confounding variables (see Lønning \& Geisler (2008) for discussion and references). In the two studies evaluating the effects of an aromatase inhibitor vs placebo in early disease, both exemestane (Lønning et al. 2005) as well as letrozole (Wasan et al. 2005) had minor effects on plasma lipid levels. Considering cardiovascular events in the phase III trials comparing aromatase inhibitors to tamoxifen (Table 4), there is no substantial evidence suggesting detrimental effects of aromatase inhibitors with respect to cardiovascular morbidity and mortality in early breast cancer (Jakesz et al. 2005, Boccardo et al. 2006, 2013, Kaufmann et al. 2007, Forbes et al. 2008, Colleoni et al. 2011, van de Velde et al. 2011, Bliss et al. 2012, Dubsky et al. 2012).

A third type of side effects now receiving more attention is musculoskeletal: joint pain and stiffness, including carpal tunnel syndrome (Morales et al. 2007, Nishihori et al. 2008, Dizdar et al. 2009, Sestak et al. 2009, Mieog et al. 2012). While most patients have moderate disturbances, there is evidence that probably $20 \%$ of the patient population do not adhere to prescribed therapy with aromatase inhibitors (Partridge et al. 2008), and musculoskeletal and joint pain may be responsible for at least $50 \%$ of these withdrawals (Dent et al. 2007). Notably, Belgian investigators reported synovial deposits detectable by magnetic resonance imaging (MRI) scans among patients suffering from tendon and joint pain (Morales et al. 2008). For these patients, tamoxifen, or probably fulvestrant, may be considered as alternative treatment options. Interestingly, it seems that certain single nucleotide polymorphisms are associated with the musculoskeletal side effects of aromatase inhibitors, related to the expression of interleukin 17 receptor A (Ingle et al. 2010). Such analysis might allow us to identify upfront patients in the future who will not tolerate aromatase inhibitors and should have another endocrine treatment.

\section{Aromatase inhibitors and obesity}

Obesity is associated with significantly elevated risk of breast cancer (Morimoto et al. 2002, Key et al. 2003) as well as a poor prognosis among postmenopausal breast cancer patients (Protani et al. 2010, Kwan et al. 2012). While the mechanisms are incompletely understood, the fact that obesity has been associated with elevated levels of $E_{2}$ in

Published by Bioscientifica Ltd. 
Table 4 Cardiovascular events in adjuvant phase III trials comparing aromatase inhibitors to tamoxifen.

\begin{tabular}{|c|c|c|c|c|c|c|}
\hline \multirow[b]{2}{*}{ Patients } & \multirow[b]{2}{*}{ Drug } & \multicolumn{3}{|c|}{ Cardiovascular events } & \multirow[b]{2}{*}{ Follow-up } & \multirow[b]{2}{*}{ References } \\
\hline & & Cardiac $A E^{a}$ & $I H D^{b}$ & Deaths ${ }^{c}$ & & \\
\hline \multicolumn{7}{|l|}{ ATAC } \\
\hline 3116 & $\mathrm{~T}$ & 3.4 & $0.27^{d}$ & 66 & 100 months & Forbes et al. (2008) \\
\hline 3125 & A & 4.1 & $0.27^{d}$ & 67 & & \\
\hline \multicolumn{7}{|l|}{ BIG 1-98 } \\
\hline 2447 & $\mathrm{~T}$ & 6.2 & 2.0 & 7 & 74 months & Colleoni et al. (2011) \\
\hline 2448 & $\mathrm{~L}$ & 6.9 & 2.8 & 10 & & \\
\hline \multicolumn{7}{|l|}{ ABCSG-8 } \\
\hline 1849 & $\mathrm{~T}$ & $4.4^{\mathrm{e}}$ & $<1.0^{d}$ & NR & 60 months & $\begin{array}{l}\text { Jakesz et al. (2005) and } \\
\text { Dubsky et al. (2012) }\end{array}$ \\
\hline 1865 & $\mathrm{~T} \rightarrow \mathrm{A}$ & $4.2^{\mathrm{e}}$ & $<1.0^{\mathrm{d}}$ & NR & & \\
\hline \multicolumn{7}{|l|}{ ARNO 95} \\
\hline 452 & $\mathrm{~T}$ & NR & 0.9 & $16^{f}$ & 30.1 months & Kaufmann et al. (2007) \\
\hline 445 & $\mathrm{~T} \rightarrow \mathrm{A}$ & NR & 2.0 & $11^{f}$ & & \\
\hline \multicolumn{7}{|l|}{ ITA } \\
\hline 225 & $\mathrm{~T}$ & 6.2 & NR & $11^{f}$ & 128 months & $\begin{array}{l}\text { Boccardo et al. (2006, } \\
\text { 2013) }\end{array}$ \\
\hline 223 & $\mathrm{~T} \rightarrow \mathrm{A}$ & 7.6 & NR & $12^{f}$ & & \\
\hline \multicolumn{7}{|l|}{ IES } \\
\hline 2036 & $\mathrm{~T}$ & 10.4 & 4.6 & 20 & 91 months & Bliss et al. (2012) \\
\hline 2105 & $\mathrm{~T} \rightarrow \mathrm{E}$ & 12.3 & 6.0 & 22 & & \\
\hline \multicolumn{7}{|l|}{ TEAM } \\
\hline 4814 & $\mathrm{~T} \rightarrow \mathrm{E}$ & 6.4 & 1.0 & 28 & 5.1 years & $\begin{array}{l}\text { van de Velde et al. } \\
\text { (2011) }\end{array}$ \\
\hline 4852 & E & $8.1^{\mathrm{g}}$ & 2.0 & 43 & & \\
\hline
\end{tabular}

T, tamoxifen; A, anastrozole; L, letrozole; $E$, exemestane; NR, not reported.

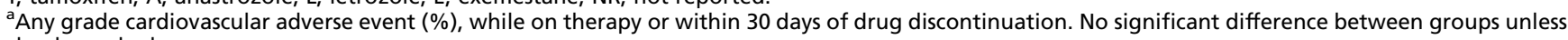
clearly marked.

b Ischemic heart disease.

${ }^{\mathrm{C}} \mathrm{Number}$ of deaths from cardiovascular causes.

dBoth cardiovascular and thromboembolic events.

e Myocardial infarction only.

${ }^{f}$ All non-cancer-related deaths.

${ }^{9}$ Significantly more cases of cardiac failure in exemestane alone group.

postmenopausal women (Meldrum et al. 1981, Poortman et al. 1981), as well as recent findings indicating that obesity may not influence outcome in triple-negative breast cancers (Dawood et al. 2012), indicate that elevated $\mathrm{E}_{2}$ levels may be (at least partly) responsible for these effects. However, others (Niraula et al. 2012) have argued that obesity may confer a poor prognosis, independent of estrogen receptor levels and menopausal status.

Recent data have thrown concern over the efficacy of aromatase inhibitors among obese individuals. The Austrian ABCSG-12 trial randomized premenopausal breast cancer patients in a $2 \times 2$ trial design to either treatment with goserelin plus tamoxifen $+/$-zoledronic acid or goserelin plus anastrozole $+/$-zoledronic acid. Recently, Pfeiler et al. (2011) reported overweight (BMI >25) to be associated with an enhanced relapse rate within the group of patients treated with anastrozole. In contrast, no detrimental effect of obesity was observed among patients treated with tamoxifen. Moreover, overweight individuals treated with anastrozole had a $50 \%$ increased risk of a relapse but a threefold increased risk of death compared with overweight patients on tamoxifen treatment. Analyzing the ATAC study, Sestak et al. (2010) found women with a BMI $>35$ to have a poor prognosis compared with lean women, independent of treatment arm (anastrozole or tamoxifen). However, there was a non-significant trend indicating a reduced benefit of anastrozole compared with tamoxifen among obese individuals. In contrast, analyzing data from the BIG 1-98 study, Ewertz et al. (2012) found the benefit of letrozole compared with tamoxifen to be independent of BMI value. The question of whether obese patients on treatment with aromatase inhibitors express elevated plasma estrogen levels compared with individuals with a normal BMI is a current issue of controversy (Diorio et al. 2012, Folkerd et al. 2012).

Taken together, data at this stage do not advocate that aromatase inhibitors should be avoided among

Published by Bioscientifica Ltd 
overweight patients. Importantly, there are several potential explanations to the effects observed in the Austrian trial. If the problem is failure on goserelin among obese individuals, this may be predicted to have little (if any) effect on patients treated with tamoxifen in concert, while it could be detrimental to the effect of anastrozole; it is well known that aromatase inhibitors may not prevent ovarian estrogen synthesis among preand perimenopausal women (Geisler \& Lønning 2005). At this stage, it may be wise to do regular plasma hormone assessment among overweight and obese premenopausal women having goserelin treatment independent of whether they receive concomitant treatment with an aromatase inhibitor or not. As for postmenopausal women receiving aromatase inhibitor monotherapy, notably, the detrimental effect of body weight observed on anastrozole treatment related to patients with a BMI $>35$. Further, the fact that no detrimental effect of obesity was recorded for patients treated with letrozole should be underlined. In vivo studies demonstrated letrozole to be significantly more potent than anastrozole in inhibiting total body in vivo aromatization (Geisler et al. 2002) and suppressing breast cancer tissue estrogen levels (Geisler et al. 2008b). In summary, while there may be some uncertainty related to the use of anastrozole among obese patients, data so far (at least with respect to letrozole) seem reassuring.

\section{Molecular markers predicting benefit to aromatase inhibitors compared with tamoxifen?}

While only about $10 \%$ of ER-positive tumors overexpress HER-2 (Sørlie et al. 2001, Penault-Llorca et al. 2009), notably about $50 \%$ of all HER-2-amplified tumors are positive for ER expression, although at low or moderate levels (Untch et al. 2008, Penault-Llorca et al. 2009). Comparing letrozole with tamoxifen as pre-surgical therapy, Ellis et al. (2001) reported a particular superiority for letrozole over tamoxifen in tumors overexpressing either HER-1 or HER-2. Moreover, they reported letrozole to provide a particular benefit compared with tamoxifen for patients with tumors revealing a moderate Allred ER score. However, these findings have not been reproduced in the phase III adjuvant studies. Thus, data from the TransATAC, comparing anastrozole with tamoxifen (Dowsett et al. 2008), as well as the BIG 1-98, comparing letrozole with tamoxifen (Rasmussen et al. 2008), revealed a higher relapse rate for patients with HER-2-positive vs HER-2-negative tumors in the aromatase inhibitor as well as in the tamoxifen-treated arm. The relative benefit for the aromatase inhibitor over tamoxifen, however, was similar in both patient groups. Similarly, separating patients into quartiles based on ER expression status, Dowsett et al. (2008), found the relative benefit from anastrozole over tamoxifen to be independent of ER expression status.

Notably, adding either trastuzumab (Kaufman et al. 2009) or lapatinib (Johnston et al. 2009) to treatment with an aromatase inhibitor in patients with ER +/HER-2+ metastatic breast cancer improves time to progression. Whether this relates to reversal of endocrine resistance or, simply, to different treatment options administered in concert is not known. However, experimental studies have revealed cross talk between HER- 2 and ER signaling mediated via both the PI3K-Akt-mTOR and the Ras-RafMEK-MAPK pathways (Campbell et al. 2001, Knowlden et al. 2003, Jordan et al. 2004, Jelovac et al. 2005). Interestingly, the study by Johnston et al. (2009) also included patients with ER-positive tumors harboring a normal HER-2 status. While no benefit for lapatinib was recorded among HER-2-negative tumors on an intentionto-treat basis, a pre-defined analysis revealed superiority for lapatinib in a subgroup of HER-2 non-amplified tumors with an early relapse on tamoxifen. Potential interactions between the HER-2 and ER pathways should be further examined. Accordingly, we found that primary treatment with aromatase inhibitors may increase tumor HER-2 levels in non-amplified tumors (Flageng et al. 2009). Currently, the GCC 0901 study examines the effect of adding the mTOR inhibitor everolimus to patients progressing on letrozole and lapatinib in concert (ClinicalTrials.gov \#NCT01499160). However, in HER-2 overexpressing breast cancer, PI3K signaling inhibition leads to increased HER-2-mediated ERK activation, pointing to yet another important growth-promoting signaling axis, the Ras-Raf-MEK-ERK pathway (Fig. 2), and the potential need for adding for instance MEK inhibitors in certain patient subgroups (Serra et al. 2011).

\section{Resistance toward treatment with aromatase inhibitors: current observations related to targeted therapy}

As mentioned above, there is increasing evidence indicating that cross talk between the estrogen receptor pathway and several other growth-controlling pathways may cause resistance to aromatase inhibitors (Miller et al. 2011, Sabnis \& Brodie 2011). Accordingly, a large number of clinical trials are currently conducted to assess whether

Published by Bioscientifica Ltd. 


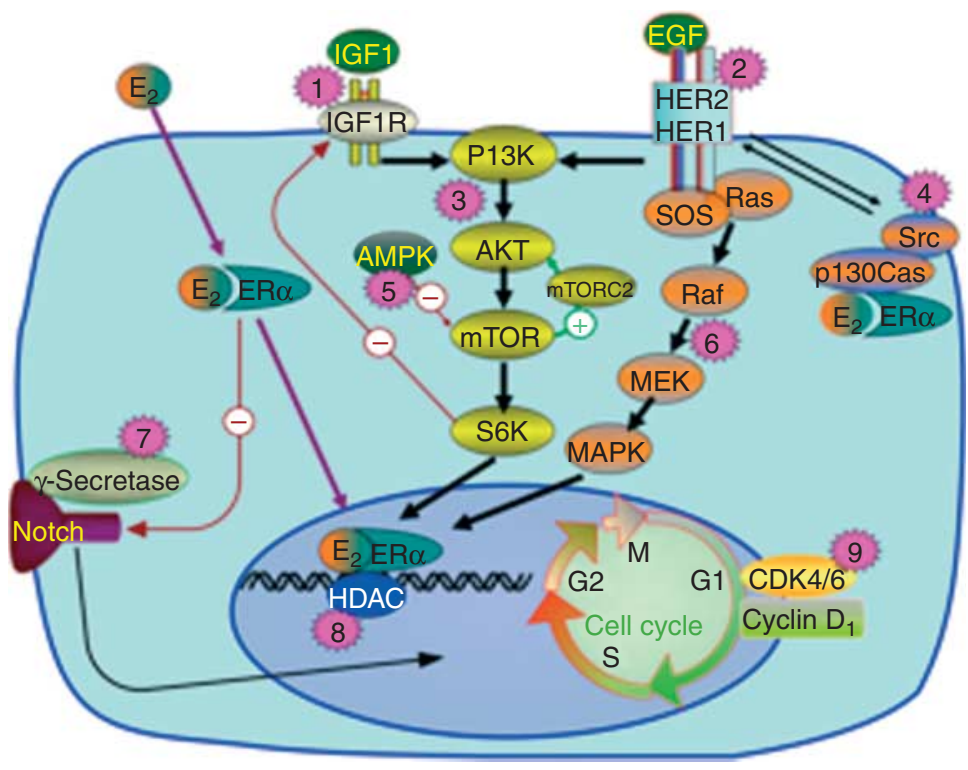

\section{Figure 2}

Signaling mechanisms important for endocrine resistance and which are currently targeted in clinical trials, combined with aromatase inhibitors. (1) IGF1 or IGF1R neutralizing antibodies (AMG-479 in study NCT00626106 a.o.). (2) HER-2 blocking therapy (trastuzumab emtansine in study NCT01745965 a.o.). (3) Inhibitors of PI3K, Akt, and/or mTOR pathway (everolimus in study NCT01698918 a.o.). (4) Src inhibitors (dasatinib in study NCT00696072 a.o.). (5) AMPK activator (metformin in study

various signal transduction inhibitors can augment the efficacy of aromatase inhibitors in postmenopausal patients with breast cancer. These include inhibitors of the PI3K-Akt-mTOR and Ras-Raf-MEK-MAPK pathways, insulin-like growth factor 1 (IGF1) receptor (IGF1R), gamma secretase/Notch, cyclin-dependent kinase 4/6 (CDK4/6), histone deacetylase (HDAC), and Src/Abl a.o. (Fig. 2), as elaborated on elsewhere (Fedele et al. 2012). For instance, adding the CDK4/6 inhibitor PD0332991 to letrozole in the first-line treatment of patients with ER + metastatic breast cancer increased PFS from 7.5 to 26.1 months in a phase II study with 165 patients (Finn et al. 2012).

The PI3K-Akt-mTOR signaling pathway has come up as a major resistance pathway in endocrine resistance, including resistance to aromatase inhibitors (Miller et al. 2011, Villarreal-Garza et al. 2012). Activating mutation in PIK3CA, the gene encoding the $\mathrm{p} 100 \alpha$ subunit of the PI3K protein, is present in $28-47 \%$ of ER-positive breast cancers, and is the single gene most frequently mutated in this disease (Miller et al. 2011). Currently, numerous studies are conducted where drugs targeting PI3K, Akt, and/or mTOR are tested in combination with aromatase inhibitors (Baselga 2011). Recently, two studies revealed
NCT01654185 a.o.). (6) Inhibitors of Ras-Raf-MEK-MAPK pathway (MEK inhibitor AZD6244, combined with fulvestrant after progression on aromatase inhibitor in NCT01160718). (7) Gamma secretase inhibitor (RO4929097 in study NCT01208441 a.o.). (8) HDAC inhibitors (vorinostat in study NCT01153672 a.o.). (9) CDK4/6 inhibitor (PD0332991 in study NCT01740427 a.o.).

that the mTOR inhibitor everolimus significantly improves time to progression in patients with ER-positive metastatic breast cancer undergoing endocrine therapy. The BOLERO-2 study randomized a total of 742 patients developing resistance to a non-steroidal aromatase inhibitor at a 2:1 ratio between exemestane plus everolimus vs exemestane monotherapy; here, median time to progression was extended from 4.1 to 10.6 months (Baselga et al. 2012). The effect seems not to be limited to the use of aromatase inhibitors; in a smaller study, Bachelot et al. (2012) found everolimus to improve time to progression among patients treated with tamoxifen. While this study indicated a benefit among patients with acquired resistance only, the number of patients was too low to allow for any definite conclusion.

However, there are results at variance. In a recent study, Wolff et al. (2013) found only a non-significant and modest benefit from adding another mTOR inhibitor temsirolimus to letrozole in aromatase inhibitor-naïve patients, independent of previous adjuvant tamoxifen therapy. While these results, like the findings by Bachelot et al. (2012), may indicate an effect of mTOR inhibition on acquired but not primary drug resistance across different compounds, more data are needed to draw any final

Published by Bioscientifica Ltd. 
conclusion. This issue will be addressed further in the BOLERO-4 phase II study, where 200 patients with metastatic breast cancer will be treated with everolimus and letrozole in the first-line setting (NCT01698918).

Furthermore, it should be recalled that the PI3K-AktmTOR pathway is involved in chemotherapy resistance as well (Lønning \& Knappskog 2013). Additionally, mTOR inhibitors have revealed antitumor efficacy across other tumor forms, indicating that they exhibit anti-tumor efficacy by themselves, not only as adjuvants to other cancer therapies (Motzer et al. 2010, Yao et al. 2010).

An interesting extension of the combined mTOR inhibitor/endocrine therapy trials in breast cancer is what to do when the treatment fails. In the BELLE-3 trial, a pan-PI3K inhibitor BKM120 or placebo is combined with fulvestrant in patients with advanced breast cancer who have progressed on an mTOR inhibitor plus endocrine therapy (NCT01633060). This trial will address whether upstream inhibition of PI3K is worthwhile in patients where an mTOR inhibitor fails. Moreover, rapamycin analogs (rapalogs), which are the kind of mTOR inhibiting drugs currently used in the clinic, mainly inhibit mTORC1 but not the mTORC2 complex (Jacinto et al. 2004, Villarreal-Garza et al. 2012), and the consequence of this is ongoing Akt activation by mTORC2 during rapalog administration (Fig. 2). Second-generation mTOR inhibitors, like PP242 and CC-223, inhibit both mTORC1 and mTORC2 (Janes et al. 2010, Weigelt et al. 2011); however, the potential benefit from this additional effect remains to be evaluated. Another important question is whether to keep the mTOR inhibitor beyond progression. In a planned phase II study by the German Breast Group, patients who exhibit progression of their disease on exemestane and everolimus change their endocrine treatment whereas everolimus is kept as the backbone (NCT01773460).

Another possible resistance mechanism has also been identified where aromatase inhibitors fail due to plateletderived growth factor receptor (PDGFR)/Abl signaling upregulation (Weigel et al. 2013). Src is a downstream hub for various signaling pathways, like EGFR and HER-2, and a potential signaling link between non-genomic ER and HER-2 via p130Cas, which might be involved in resistance to endocrine therapy (Cabodi et al. 2004, Fox et al. 2009, Vallabhaneni et al. 2011). Src, Abl, and PDGFR can be inhibited by the oral small molecule inhibitor dasatinib, which is already registered for use in chronic myeloid leukemia with BCR-ABL mutation, resistant to imatinib. Combination clinical trials of dasatinib and aromatase inhibitors are currently ongoing.
Another interesting observation regarding resistance to aromatase inhibitors relates to the in vitro phenomenon of 'estrogen hypersensitivity'. Breast cancer cells that have grown under long-term estrogen deprivation (LTED) become extremely sensitive to estrogen (Masamura et al. 1995, Santen et al. 2005). Whereas estrogen at high concentrations normally stimulates cell growth, it becomes cytotoxic in LTED cells (Lønning et al. 2001). While the exact mechanism causing LTED has not been fully elucidated, upregulation of the $\mathrm{ER} \alpha$, in addition to the PI3K-mTOR, and MAPK pathways has been shown to occur in LTED cells. Taking the concept of 'estrogen hypersensitivity' to the clinic, we demonstrated that estrogen in high doses can be used therapeutically in ER-positive breast cancer with acquired resistance to aromatase inhibitors (Lønning et al. 2001), a finding subsequently confirmed by Ellis et al. (2009).

\section{Future aspects on aromatase inhibition and issues that remain to be settled}

While aromatase inhibitors have become the standard therapy for ER + postmenopausal breast cancer, several issues remain to be settled. A current issue relates to the optimal duration of therapy. The next decade will address the question of how long aromatase inhibitors should be administered to derive the maximum benefit in the adjuvant setting. In this respect, the initial results of the ongoing MA.17 extension trial and NSABP B-42 study are expected in 2015. This primarily relates to therapeutic efficacy, but long-term toxicity is another important aspect in the adjuvant setting. Whereas the issue of toxicity has been thoroughly addressed with respect to 5 years of treatment, potential side effects related to extended therapy need to be carefully monitored.

A key issue with respect to treatment with aromatase inhibitors, like most other cancer compounds (Lønning \& Knappskog 2013), relates to the design of targeted strategies to prevent drug resistance in vivo. Currently, studies, like the POETIC trial, have been designed to specifically address this issue. We have an emerging understanding of which signaling pathways are involved in endocrine resistance and an increasing number of signal transduction inhibitors to target these pathways. However, the challenge will be which drugs to pick, how to combine them, and how they will be tolerated with respect to side effects (for the patient) and economic cost (for society).

Clearly, large phase III trials cannot be used when dozens of deregulated signaling pathways are to be

Published by Bioscientifica Ltd. 
targeted simultaneously. Importantly, new technology, such as 'next-generation deep sequencing', is becoming increasingly efficient and affordable, which, in the near future, will allow an increasing number of research laboratories to conduct complete exome sequencing of individual tumors. Such extensive understanding of each tumor's genomic profile, merged with biological evidence linking disturbances in defined growth factor pathways to endocrine resistance, has the potential to optimize endocrine therapy dramatically in the future. In studies, such as the ongoing SHIVA study in France (NCT01771458), the molecular profile of each individual cancer is used to design targeted therapy, as opposed to conventional therapy, to compare the old and new school in oncology. The therapeutic potential of such strategies will be answered shortly.

\section{Declaration of interest}

P E Lønning has received speakers honoraria and has been compensated for participating at Advisory Boards for Pfizer, Inc., Astra-Zeneca and Novartis, and for writing conference proceedings for Novartis. H P Eikesdal has received speakers' honoraria and has been compensated for participating at Advisory Boards for GlaxoSmithKline and Bristol Myers Squibb and has been compensated for writing conference proceedings for Novartis. Both authors are active participants in the Belle-3 study conducted by Novartis (P E Lønning is a member of the International Steering Committee).

\section{Funding}

The work providing the basis for this review has been supported by generous grants from Helse Vest, the Norwegian Cancer Society, and Bergen Medical Research Foundation.

\section{Acknowledgements}

The work from the authors' laboratory referred to in the text was mainly supported by the Norwegian Cancer Society. The authors are grateful to Gørill Skaale Johansen at the University of Bergen for preparing the Fig. 1 drawing.

\section{References}

Agarwal VR, Bulun SE, Leitch M, Rohrich R \& Simpson ER 1996 Use of alternative promoters to express the aromatase cytochrome $\mathrm{p} 450$ (CYP19) gene in breast adipose tissues of cancer-free and breast cancer patients. Journal of Clinical Endocrinology and Metabolism 81 3843-3849. (doi:10.1210/jc.81.11.3843)

Alexander KP, Newby LK, Hellkamp AS, Harrington RA, Peterson ED, Kopecky S, Langer A, O'Gara P, O'Connor CM, Daly RN et al. 2001 Initiation of hormone replacement therapy after acute myocardial infarction is associated with more cardiac events during follow-up. Journal of the American College of Cardiology 38 1-7. (doi:10.1016/S07351097(01)01329-8)

Anderson GL, Limacher M, Assaf AR, Bassford T, Beresford SAA, Black H, Bonds D, Brunner R, Brzyski R, Caan B et al. 2004 Effects of conjugated, equine estrogen in postmenopausal women with hysterectomy - The
Women's Health Initiative Randomized Controlled trial. Journal of the American Medical Association 291 1701-1712. (doi:10.1001/jama.291. 14.1701)

Anker G, Lønning PE, Ueland PM, Refsum H \& Lien EA 1995 Plasma levels of the atherogenic amino acid homocysteine in post-menopausal women with breast cancer treated with tamoxifen. International Journal of Cancer 60 365-368. (doi:10.1002/ijc.2910600316)

Bachelot T, Bourgier C, Cropet C, Ray-Coquard I, Ferrero JM, Freyer G, Abadie-Lacourtoisie S, Eymard JC, Debled M, Spaëth D et al. 2012 Randomized phase II trial of everolimus in combination with tamoxifen in patients with hormone receptor-positive, human epidermal growth factor receptor 2-negative metastatic breast cancer with prior exposure to aromatase inhibitors: a GINECO study. Journal of Clinical Oncology 30 2718-2724. (doi:10.1200/JCO.2011.39.0708)

Baselga J 2011 Targeting the phosphoinositide-3 (PI3) kinase pathway in breast cancer. Oncologist 16 12-19. (doi:10.1634/theoncologist. 2011-S1-12)

Baselga J, Campone M, Piccart M, Burris HA, Rugo HS, Sahmoud T, Noguchi S, Gnant M, Pritchard KI, Lebrun F et al. 2012 Everolimus in postmenopausal hormone-receptor-positive advanced breast cancer. New England Journal of Medicine 366 520-529. (doi:10.1056/ NEJMoa1109653)

Beatson GT 1896 On the treatment of inoperable cases of carcinoma of the mamma. Suggestions for a new method of treatment with illustrative cases. Lancet 2 104-107. (doi:10.1016/S0140-6736(01)72307-0)

Bliss JM, Kilburn LS, Coleman RE, Forbes JF, Coates AS, Jones SE, Jassem J, Delozier T, Andersen J, Paridaens R et al. 2012 Disease-related outcomes with long-term follow-up: an updated analysis of the Intergroup Exemestane Study. Journal of Clinical Oncology 30 709-717. (doi:10.1200/JCO.2010.33.7899)

Boccardo F, Rubagotti A, Guglielmini P, Fini A, Paladini G, Mesiti M, Rinaldini M, Scali S, Porpiglia M, Benedetto C et al. 2006 Switching to anastrozole versus continued tamoxifen treatment of early breast cancer. Updated results of the Italian Tamoxifen Anastrozole (ITA) trial. Annals of Oncology 17 VII10-VII14. (doi:10.1093/annonc/mdl941)

Boccardo F, Guglielmini P, Bordonaro R, Fini A, Massidda B, Porpiglia M, Roagna R, Serra P, Orzalesi L, Ucci G et al. 2013 Switching to anastrozole versus continued tamoxifen treatment of early breast cancer: long term results of the Italian Tamoxifen Anastrozole trial. European Journal of Cancer 49 1546-1554. (doi:10.1016/j.ejca.2012.12.025)

Bonaa KH, Njolstad I, Ueland PM, Schirmer H, Tverdal A, Steigen T, Wang H, Nordrehaug JE, Arnesen E, Rasmussen K et al. 2006 Homocysteine lowering and cardiovascular events after acute myocardial infarction. New England Journal of Medicine $\mathbf{3 5 4}$ 1578-1588. (doi:10.1056/NEJMoa055227)

Brodie AMH, Schwarzel WC, Shaikh AA \& Brodie HJ 1977 The effect of an aromatase inhibitor, 4-hydroxy-androstene-3,17-dione, on estrogendependent processes in reproduction and breast cancer. Endocrinology 100 1684-1695. (doi:10.1210/endo-100-6-1684)

Brodie AMH, Garrett WM, Hendrickson JR, Tsai-Morris CH \& Williams JG 1983 Aromatase inhibitors, their pharmacology and application. Journal of Steroid Biochemistry 19 53-58. (doi:10.1016/S00224731(83)80006-5)

Bulun SE, Sebastian S, Takayama K, Suzuki T, Sasano H \& Shozu M 2003 The human CYP19 (aromatase P450) gene: update on physiologic roles and genomic organization of promoters. Journal of Steroid Biochemistry and Molecular Biology 86 219-224. (doi:10.1016/S0960-0760(03)00359-5)

Cabodi S, Moro L, Baj G, Smeriglio M, Di Stefano P, Gippone S, Surico N, Silengo L, Turco E, Tarone G et al. 2004 p130Cas interacts with estrogen receptor $\alpha$ and modulates non-genomic estrogen signaling in breast cancer cells. Journal of Cell Science 117 1603-1611. (doi:10.1242/ jcs.01025)

Campbell RA, Bhat-Nakshatri P, Patel NM, Constantinidou D, Ali S \& Nakshatri H 2001 Phosphatidylinositol 3-kinase/AKT-mediated activation of estrogen receptor $\alpha-$ a new model for anti-estrogen resistance. 
Journal of Biological Chemistry 276 9817-9824. (doi:10.1074/jbc. M010840200)

Cash R, Brough AJ, Cohen MNP \& Satoh PS 1967 Aminoglutethimide (Elipten-Ciba) is an inhibitor of adrenal steroidogenesis: mechanism of action and therapeutic trial. Journal of Clinical Endocrinology and Metabolism 27 1239-1248. (doi:10.1210/jcem-27-9-1239)

Cataliotti L, Buzdar AU, Noguchi S, Bines J, Takatsuka Y, Petrakova K, Dube P \& de Oliveira CT 2006 Comparison of anastrozole versus tamoxifen as preoperative therapy in postmenopausal women with hormone receptor-positive breast cancer - The Pre-Operative 'Arimidex' Compared to Tamoxilen (PROAC7) trial. Cancer 106 2095-2103. (doi:10.1002/cncr.21872)

Chia S, Gradishar W, Mauriac L, Bines J, Amant F, Federico M, Fein L, Romieu G, Buzdar A, Robertson JF et al. 2008 Double-blind, randomized placebo controlled trial of fulvestrant compared with exemestane after prior nonsteroidal aromatase inhibitor therapy in postmenopausal women with hormone receptor-positive, advanced breast cancer: results from EFECT. Journal of Clinical Oncology 26 1664-1670. (doi:10.1200/JCO.2007.13.5822)

Clyne CD, Kovacic A, Speed CJ, Zhou J, Pezzi V \& Simpson ER 2004 Regulation of aromatase expression by the nuclear receptor LRH-1 in adipose tissue. Molecular and Cellular Endocrinology 215 39-44. (doi:10.1016/j.mce.2003.11.001)

Coates AS, Keshaviah A, Thurlimann B, Mouridsen H, Mauriac L, Forbes JF, Paridaens R, Castiglione-Gertsch M, Gelber RD, Colleoni M et al. 2007 Five years of letrozole compared with tamoxifen as initial adjuvant therapy for postmenopausal women with endocrine-responsive early breast cancer: update of study BIG 1-98. Journal of Clinical Oncology 25 486-492. (doi:10.1200/JCO.2006.08.8617)

Coleman R, Banks L, Girgis S, Kilburn L, Vrdoljak E, Fox J, Cawthorn SJ, Patel A, Snowdon CF, Hall E et al. 2007 Skeletal effects of exemestane on bone-mineral density bone biomarkers and fracture incidence in postmenopausal women with early breast cancer participating in the Intergroup Exemestane Study (IES): a randomised controlled study. Lancet Oncology 8 119-127. (doi:10.1016/S1470-2045(07)70003-7)

Colleoni M, Giobbie-Hurder A, Regan MM, Thurlimann B, Mouridsen H, Mauriac L, Mauriac L, Forbes JF, Paridaens R, Láng I et al. 2011 Analyses adjusting for selective crossover show improved overall survival with adjuvant letrozole compared with tamoxifen in the BIG 1-98 Study. Journal of Clinical Oncology 29 1117-1124. (doi:10.1200/JCO.2010. 31.6455)

Coombes RC, Goss P, Dowsett M, Gazet J-C \& Brodie A 1984 4-Hydroxyandrostenedione in treatment of postmenopausal patients with advanced breast cancer. Lancet 324 1237-1239. (doi:10.1016/ S0140-6736(84)92795-8)

Coombes RC, Kilburn LS, Snowdon CF, Paridaens R, Coleman RE, Jones SE, Jassem J, Van de Velde CJ, Delozier T, Alvarez I et al. 2007 Survival and safety of exemestane versus tamoxifen after 2-3 years' tamoxifen treatment (Intergroup Exemestane Study): a randomised controlled trial. Lancet 369 559-570. (doi:10.1016/S0140-6736(07)60200-1)

Couzinet B, Meduri G, Lecce M, Young J, Brailly S, Loosfelt H, Milgrom E \& Schaison G 2001 The postmenopausal ovary is not a major androgenproducing gland. Journal of Clinical Endocrinology and Metabolism $\mathbf{8 6}$ 5060-5066. (doi:10.1210/jc.86.10.5060)

Davies C, Pan HC, Godwin J, Gray R, Peto R \& Collaboratives A 2012 ATLAS - 10 v 5 years of adjuvant tamoxifen (TAM) in ER + disease; effects on outcome in the first and second decade after diagnosis. Cancer Research 72 (24 suppl) S81-S82.

Dawood S, Lei XD, Litton JK, Buchholz TA, Hortobagyi GN \& Gonzalez-Angulo AM 2012 Impact of body mass index on survival outcome among women with early stage triple-negative breast cancer. Clinical Breast Cancer 12 364-372. (doi:10.1016/j.clbc.2012.07.013)

Dent S, Hopkins S, Di Valentin T, Verreault J, Vandermeer L \& Verma S 2007 Adjuvant aromatase inhibitors in early breast cancer - toxicity and adherence. Important observations in clinical practice. Breast Cancer Research and Treatment 106 (S1) S111.
Diorio C, Lemieux J, Provencher L, Hogue JC \& Vachon E 2012 Aromatase inhibitors in obese breast cancer patients are not associated with increased plasma estradiol levels. Breast Cancer Research and Treatment 136 573-579. (doi:10.1007/s10549-012-2278-z)

Dixon JM, Renshaw L, Young O, Murray J, Macaskill EJ, McHugh M, Folkerd E, Cameron DA, A'Hern RP \& Dowsett M 2008 Letrozole suppresses plasma estradiol and estrone sulphate more completely than anastrozole in postmenopausal women with breast cancer. Journal of Clinical Oncology 26 1671-1676. (doi:10.1200/JCO.2007.13.9279)

Dixon JM, Renshaw L, Macaskill EJ, Young O, Murray J, Cameron D, Kerr GR, Evans DB \& Miller WR 2009 Increase in response rate by prolonged treatment with neoadjuvant letrozole. Breast Cancer Research and Treatment 113 145-151. (doi:10.1007/s10549-008-9915-6)

Dizdar O, Ozcakar L, Malas FU, Harputluoglu H, Bulut N, Aksoy S, Ozisik Y \& Altundag K 2009 Sonographic and electrodiagnostic evaluations in patients with aromatase inhibitor-related arthralgia. Journal of Clinical Oncology 27 4955-4960. (doi:10.1200/JCO.2008.20.5435)

Dowsett M, Goss PE, Powles TJ, Hutchinson G, Brodie AMH, Jeffcoate SL \& Coombes RC 1987 Use of the aromatase inhibitor 4-hydroxyandrostenedione in postmenopausal breast cancer: optimization of therapeutic dose and route. Cancer Research 47 1957-1961.

Dowsett M, Cantwell B, Lal A, Jeffcoate SL \& Harris AL 1988 Suppression of postmenopausal ovarian steroidogenesis with the luteinizing hormone-releasing hormone agonist goserelin. Journal of Clinical Endocrinology and Metabolism 66 672-677. (doi:10.1210/jcem-66-4-672)

Dowsett M, Jones A, Johnston SRD, Jacobs S, Trunet P \& Smith IE 1995 In vivo measurement of aromatase inhibition by letrozole (CGS 20267) in post menopausal patients with breast cancer. Clinical Cancer Research 1 1511-1515.

Dowsett M, Smith IE, Ebbs SR, Dixon JM, Skene A, Griffith C, Boeddinghaus I, Salter J, Detre S \& Hills M 2005 Short-term changes in Ki-67 during neoadjuvant treatment of primary breast cancer with anastrozole or tamoxifen alone or combined correlate with recurrence-free survival. Clinical Cancer Research 11 951S-958S.

Dowsett M, Smith IE, Ebbs SR, Dixon JM, Skene A, A'Hern R, Salter J, Detre S, Hills M, Walsh G et al. 2007 Prognostic value of Ki67 expression after short-term presurgical endocrine therapy for primary breast cancer. Journal of the National Cancer Institute 99 167-170. (doi:10.1093/jnci/ djk020)

Dowsett M, Allred C, Knox J, Quinn E, Salter J, Wale C, Cuzick J, Houghton J, Williams N, Mallon E et al. 2008 Relationship between quantitative estrogen and progesterone receptor expression and human epidermal growth factor receptor 2 (HER-2) status with recurrence in the arimidex, tamoxifen, alone or in combination trial. Journal of Clinical Oncology 26 1059-1065. (doi:10.1200/JCO.2007.12.9437)

Dowsett M, Cuzick J, Ingle J, Coates A, Forbes J, Bliss J, Buyse M, Baum M, Buzdar A, Colleoni M et al. 2010 Meta-analysis of breast cancer outcomes in adjuvant trials of aromatase inhibitors versus tamoxifen. Journal of Clinical Oncology 28 509-518. (doi:10.1200/JCO.2009.23. 1274)

Dowsett M, Nielsen TO, A'Hern R, Bartlett J, Coombes RC, Cuzick J, Ellis M, Henry NL, Hugh JC, Lively T et al. 2011a Assessment of Ki67 in breast cancer: recommendations from the International Ki67 in Breast Cancer Working Group. Journal of the National Cancer Institute 103 1656-1664. (doi:10.1093/jnci/djr393)

Dowsett M, Smith I, Robertson J, Robison L, Pinhel I, Johnson L, Salter J, Dunbier A, Anderson H \& Ghazoui Z $2011 b$ Endocrine therapy, new biologicals, and new study designs for presurgical studies in breast cancer. Journal of the National Cancer Institute. Monographs 2011 120-123. (doi:10.1093/jncimonographs/lgr034)

Dubsky PC, Jakesz R, Mlineritsch B, Postlberger S, Samonigg H, Kwasny W, Tausch C, Stöger H, Haider K, Fitzal F et al. 2012 Tamoxifen and anastrozole as a sequencing strategy: a randomized controlled trial in postmenopausal patients with endocrine-responsive early breast cancer From the Austrian Breast and Colorectal Cancer Study Group. Journal of Clinical Oncology 30 722-728. (doi:10.1200/JCO.2011.36.8993) 
Eastell R, Adams JE, Coleman RE, Howell A, Hannon RA, Cuzick J, MackeyJR, Beckmann MW \& Clack G 2008 Effect of anastrozole on bone mineral density: 5-year results from the anastrozole, tamoxifen, alone or in combination trial 18233230. Journal of Clinical Oncology 26 1051-1058. (doi:10.1200/JCO.2007.11.0726)

Eiermann W, Paepke S, Appfelstaedt J, LlombartCussac A, Eremin J, Vinholes J, Mauriac L, Ellis M, Lassus M, Chaudri-Ross HA et al. 2001 Preoperative treatment of postmenopausal breast cancer patients with letrozole: a randomized double-blind multicenter study. Annals of Oncology 12 1527-1532. (doi:10.1023/A:1013128213451)

Ellis MJ, Coop A, Singh B, Mauriac L, Llombert-Cussac A, Janicke F, Miller WR, Evans DB, Dugan M, Brady C et al. 2001 Letrozole is more effective neoadjuvant endocrine therapy than tamoxifen for ErbB-1and/or ErbB-2-positive, estrogen receptor-positive primary breast cancer: evidence from a phase III randomized trial. Journal of Clinical Oncology 19 3808-3816.

Ellis MJ, Gao F, Dehdashti F, Jeffe DB, Marcom PK, Carey LA, Dickler MN, Silverman P, Fleming GF, Kommareddy A et al. 2009 Lower-dose vs high-dose oral estradiol therapy of hormone receptor-positive, aromatase inhibitor-resistant advanced breast cancer a phase 2 randomized study. Journal of the American Medical Association 302 774-780. (doi:10.1001/jama.2009.1204)

Engan T, Krane J, Johannessen DC, Lonning PE \& Kvinnsland S 1995 Plasma changes in breast cancer patients during endocrine therapy lipid measurements and nuclear magnetic resonance (NMR) spectroscopy. Breast Cancer Research and Treatment 36 287-297. (doi:10.1007/BF00713400)

Ewertz M, Gray KP, Regan MM, Ejlertsen B, Price KN, Thurlimann B, Bonnefoi H, Forbes JF, Paridaens RJ, Rabaglio M et al. 2012 Obesity and risk of recurrence or death after adjuvant endocrine therapy with letrozole or tamoxifen in the Breast International Group 1-98 trial. Journal of Clinical Oncology 30 3967-3975. (doi:10.1200/JCO.2011. 40.8666)

Fedele P, Calvani N, Marino A, Orlando L, Schiavone P, Quaranta A \& Cinieri S 2012 Targeted agents to reverse resistance to endocrine therapy in metastatic breast cancer: where are we now and where are we going? Critical Reviews in Oncology/Hematology 84 243-251. (doi:10.1016/j.critrevonc.2012.03.004)

Finn RS, Crown JP, Lang I, Boer K, Bondarenko IM, Kulyk SO, Ettl J, Patel R, Pinter T, Schmidt M et al. 2012 Results of a randomized phase 2 study of PD 0332991, a cyclin-dependent kinase (CDK) 4/6 inhibitor, in combination with letrozole vs letrozole alone for first-line treatment of ER+/HER2 - advanced breast cancer (BC). Cancer Research 72 (24 Suppl) S1-S6.

Fisher B, Dignam J, Bryant J, Decillis A, Wickerham DL, Wolmark N, Costantino J, Redmond C, Fisher ER, Bowman DM et al. 1996 Five versus more than five years of tamoxifen therapy for breast cancer patients with negative lymph nodes and estrogen receptor-positive tumors. Journal of the National Cancer Institute 88 1529-1542. (doi:10.1093/jnci/88.21.1529)

Flageng MH, Moi LL, Dixon JM, Geisler J, Lien EA, Miller WR, Lønning PE \& Mellgren G 2009 Nuclear receptor co-activators and HER-2/neu are upregulated in breast cancer patients during neo-adjuvant treatment with aromatase inhibitors. British Journal of Cancer 101 1253-1260. (doi:10.1038/sj.bjc.6605324)

Folkerd EJ, Dixon JM, Renshaw L, A'Hern RP \& Dowsett M 2012 Suppression of plasma estrogen levels by letrozole and anastrozole is related to body mass index in patients with breast cancer. Journal of Clinical Oncology 30 2977-2980. (doi:10.1200/JCO.2012.42.0273)

Forbes JF, Cuzick J, Buzdar A, Howell A, Tobias JS \& Baum M 2008 Effect of anastrozole and tamoxifen as adjuvant treatment for early-stage breast cancer: 100-month analysis of the ATAC trial. Lancet Oncology 9 45-53. (doi:10.1016/S1470-2045(07)70385-6)

Fox EM, Andrade J \& Shupnik MA 2009 Novel actions of estrogen to promote proliferation: Integration of cytoplasmic and nuclear pathways. Steroids $\mathbf{7 4}$ 622-627. (doi:10.1016/j.steroids.2008.10.014)
Fracchia AA, Randall HT \& Farrow JH 1967 The results of adrenalectomy in advanced breast cancer in 500 consecutive patients. Surgery, Gynecology \& Obstetrics 125 747-756.

Fracchia AA, Farrow JH, Miller TR, Tollefsen RH, Greenberg EJ \& Knapper WH 1971 Hypophysectomy as compared with adrenalectomy in the treatment of advanced carcinoma of the breast. Surgery, Gynecology \& Obstetrics 133 241-246.

Geisler J \& Lønning PE 2005 Aromatase inhibition: translation into a successful therapeutic approach. Clinical Cancer Research 11 2809-2821. (doi:10.1158/1078-0432.CCR-04-2187)

Geisler J, Haarstad H, Gundersen S, Raabe N, Kvinnsland S \& Lonning PE 1995 Influence of treatment with the anti-oestrogen 3-hydroxytamoxifen (droloxifene) on plasma sex hormone levels in postmenopausal patients with breast cancer. Journal of Endocrinology 146 359-363. (doi:10.1677/joe.0.1460359)

Geisler J, Johannessen DC, Anker G \& Lønning PE 1996a Treatment with formestane alone and in combination with aminoglutethimide in heavily pretreated cancer patients: clinical and endocrine effects. European Journal of Cancer 32A 789-792. (doi:10.1016/09598049(95)00623-0)

Geisler J, King N, Dowsett M, Ottestad L, Lundgren S, Walton P, Kormeset PO \& Lønning PE $1996 b$ Influence of anastrozole (arimidex), a selective, non-steroidal aromatase inhibitor, on in vivo aromatisation and plasma oestrogen levels in postmenopausal women with breast cancer. British Journal of Cancer 74 1286-1291. (doi:10.1038/bjc. 1996.531)

Geisler J, King N, Anker G, Ornati G, Di Salle E, Lønning PE \& Dowsett M 1998 In vivo inhibition of aromatization by exemestane, a novel irreversible aromatase inhibitor, in postmenopausal breast cancer patients. Clinical Cancer Research 4 2089-2093.

Geisler J, Detre S, Berntsen H, Ottestad L, Lindtjørn B, Dowsett M \& Lønning P 2001 Influence of neoadjuvant anastrozole (Arimidex) on intratumoral estrogen levels and proliferation markers in patients with locally advanced breast cancer. Clinical Cancer Research 7 1230-1236.

Geisler J, Haynes B, Anker G, Dowsett M \& Lønning PE 2002 Influence of letrozole (Femara) and anastrozole (Arimidex) on total body aromatization and plasma estrogen levels in postmenopausal breast cancer patients evaluated in a randomized, cross-over-designed study. Journal of Clinical Oncology 20 751-757. (doi:10.1200/JCO.20.3.751)

Geisler J, Lønning PE, Krag LE, Løkkevik E, Risberg T, Hagen AI, Schlichting E, Lien EA, Ofjord ES \& Eide GE 2006 Changes in bone and lipid metabolism in postmenopausal women with early breast cancer after terminating 2-year treatment with exemestane: a randomised, placebo-controlled study. European Journal of Cancer 42 2968-2975. (doi:10.1016/j.ejca.2006.07.005)

Geisler J, Ekse D, Helle H, Duong N \& Lønning P 2008a An optimised, highly sensitive radioimmunoassay for the simultaneous measurement of estrone, estradiol and estrone sulfate in the ultra-low range in human plasma samples. Journal of Steroid Biochemistry and Molecular Biology 109 90-95. (doi:10.1016/j.jsbmb.2007.12.011)

Geisler J, Helle H, Ekse D, Duong NK, Evans DB, Nordbø Y, Aas T \& Lønning PE $2008 b$ Letrozole is superior to anastrozole in suppressing breast cancer tissue and plasma estrogen levels. Clinical Cancer Research 14 6330-6335. (doi:10.1158/1078-0432.CCR-07-5221)

Gnant M, Mlineritsch B, Luschin-Ebengreuth G, Kainberger F, Kässmann H, Piswanger-Sölkner JC, Seifert M, Ploner F, Menzel C, Dubsky P et al. 2008 Adjuvant endocrine therapy plus zoledronic acid in premenopausal women with early-stage breast cancer: 5-year follow-up of the ABCSG-12 bone-mineral density substudy. Lancet Oncology 9 840-849. (doi:10.1016/S1470-2045(08)70204-3)

Goss PE, Ingle JN, Martino S, Robert NJ, Muss HB, Piccart MJ, Castiglione M, Tu D, Shepherd LE, Pritchard KI et al. 2005 Randomized trial of letrozole following tamoxifen as extended adjuvant therapy in receptor-positive breast cancer: updated findings from NCICCTG MA.17. Journal of the National Cancer Institute 97 1262-1271. (doi:10.1093/jnci/dji250) 
Harris AL, Cantwell BMJ \& Dowsett M 1988 High dose ketoconazole: endocrine and therapeutic effects in postmenopausal breast cancer. British Journal of Cancer 58 493-496. (doi:10.1038/bjc.1988.247)

Haynes BP, Straume AH, Geisler J, A'Hern R, Helle H, Smith IE, Lønning PE \& Dowsett M 2010 Intratumoral estrogen disposition in breast cancer. Clinical Cancer Research 16 1790-1801. (doi:10.1158/1078-0432. CCR-09-2481)

Howell A, Robertson JF, Quaresma Albano J, Aschermannova A, Mauriac L, Kleeberg UR, Vergote I, Erikstein B, Webster A, Morris C et al. 2002 Fulvestrant, formerly ICI 182,780 , is as effective as anastrozole in postmenopausal women with advanced breast cancer progressing after prior endocrine treatment. Journal of Clinical Oncology 20 3396-3403. (doi:10.1200/JCO.2002.10.057)

Howell A, Robertson JF, Abram P, Lichinitser MR, Elledge R, Bajetta E, Watanabe T, Morris C, Webster A, Dimery I et al. 2004 Comparison of fulvestrant versus tamoxifen for the treatment of advanced breast cancer in postmenopausal women previously untreated with endocrine therapy: a multinational, double-blind, randomized trial. Journal of Clinical Oncology 22 1605-1613. (doi:10.1200/JCO.2004.02.112)

Huggins C \& Dao TL-Y 1953 Adrenalectomy and oophorectomy in treatment of advanced carcinoma of the breast. Journal of the American Medical Association 151 1388-1394.

Hulley S, Grady D, Bush T, Furberg C, Herrington D, Riggs B \& Vittinghoff E 1998 Randomized trial of estrogen plus progestin for secondary prevention of coronary heart disease in postmenopausal women. Journal of the American Medical Association 280 605-613. (doi:10.1001/ jama.280.7.605)

Ingle JN, Schaid DJ, Goss PE, Liu M, Mushiroda T, Chapman JA, Kubo M, Jenkins GD, Batzler A, Shepherd L et al. 2010 Genome-wide associations and functional genomic studies of musculoskeletal adverse events in women receiving aromatase inhibitors. Journal of Clinical Oncology 28 4674-4682. (doi:10.1200/JCO.2010.28.5064)

Jacinto E, Loewith R, Schmidt A, Lin S, Rüegg MA, Hall A \& Hall MN 2004 Mammalian TOR complex 2 controls the actin cytoskeleton and is rapamycin insensitive. Nature Cell Biology 6 U1122-U1130. (doi:10.1038/ncb1183)

Jacobs S, Lønning PE, Haynes B, Griggs L \& Dowsett M 1991 Measurement of aromatisation by a urine technique suitable for the evaluation of aromatase inhibitors in vivo. Journal of Enzyme Inhibition 4 315-325. (doi:10.3109/14756369109030396)

Jakesz R, Jonat W, Gnant M, Mittlboeck M, Greil R, Tausch C, Hilfrich J, Kwasny W, Menzel C, Samonigg H et al. 2005 Switching of postmenopausal women with endocrine-responsive early breast cancer to anastrozole after 2 years' adjuvant tamoxifen: combined results of ABCSG trial 8 and ARNO 95 trial. Lancet 366 455-462. (doi:10.1016/ S0140-6736(05)67059-6)

Jakesz R, Greil R, Gnant M, Schmid M, Kwasny W, Kubista E, Mlineritsch B, Tausch C, Stierer M, Hofbauer F et al. 2007 Extended adjuvant therapy with anastrozole among postmenopausal breast cancer patients: results from the randomized Austrian Breast and Colorectal Cancer Study Group trial 6a. Journal of the National Cancer Institute 99 1845-1853. (doi:10.1093/jnci/djm246)

Janes MR, Limon JJ, So L, Chen J, Lim RJ, Chavez MA, Vu C, Lilly MB, Mallya S, Ong ST et al. 2010 Effective and selective targeting of leukemia cells using a TORC1/2 kinase inhibitor. Nature Medicine 16 205-213. (doi:10.1038/nm.2091)

Jelovac D, Sabnis G, Long BJ, Macedo L, Goloubeva OG \& Brodie AMH 2005 Activation of mitogen-activated protein kinase in xenografts and cells during prolonged treatment with aromatase inhibitor letrozole. Cancer Research 65 5380-5389. (doi:10.1158/0008-5472. CAN-04-4502)

Johannessen DC, Engan T, Di Salle E, Zurlo MG, Paolini J, Ornati G, Piscitelli G, Kvinnsland S \& Lonning PE 1997 Endocrine and clinical effects of exemestane (PNU 155971), a novel steroidal aromatase inhibitor, in postmenopausal breast cancer patients: a phase I study. Clinical Cancer Research 3 1101-1108.
Johnell O, Kanis JA, Odén A, Sernbo I, Redlund-Johnell I, Petterson C, De Laet C \& Jönsson B 2004 Mortality after osteoporotic fractures. Osteoporosis International 15 38-42. (doi:10.1007/s00198-003-1490-4)

Johnston S, Pippen J, Jr, Pivot X, Lichinitser M, Sadeghi S, Dieras V, Gomez HL, Romieu G, Manikhas A, Kennedy MJ et al. 2009 Lapatinib combined with letrozole versus letrozole and placebo as first-line therapy for postmenopausal hormone receptor-positive metastatic breast cancer. Journal of Clinical Oncology 27 5538-5546. (doi:10.1200/ JCO.2009.23.3734)

Jones AL, MacNeill F, Jacobs S, Lønning PE, Dowsett M \& Powles TJ 1992 The influence of intramuscular 4-hydroxyandrostenedione on peripheral aromatisation in breast cancer patients. European Journal of Cancer 28A 1712-1716. (doi:10.1016/0959-8049(92)90074-C)

Jones ME, Thorburn AW, Britt KL, Hewitt KN, Misso ML, Wreford NG, Proietto J, Oz OK, Leury BJ, Robertson KM et al. 2001 Aromatasedeficient (ArKO) mice accumulate excess adipose tissue. Journal of Steroid Biochemistry and Molecular Biology 79 3-9. (doi:10.1016/S09600760(01)00136-4)

Jordan NJ, Gee JMW, Barrow D, Wakeling AE \& Nicholson RI 2004 Increased constitutive activity of $\mathrm{PKB} / \mathrm{Akt}$ in tamoxifen resistant breast cancer MCF-7 cells. Breast Cancer Research and Treatment 87 167-180. (doi:10.1023/B:BREA.0000041623.21338.47)

Kanis JA, Johnell O, De Laet C, Jonsson B, Oden A \& Ogelsby AK 2002 International variation in hip fracture probabilities: implications for risk assessment. Journal of Bone and Mineral Research 17 1237-1244. (doi:10.1359/jbmr.2002.17.7.1237)

Kaufman B, Mackey JR, Clemens MR, Bapsy PP, Vaid A, Wardley A, Tjulandin S, Jahn M, Lehle M, Feyereislova A et al. 2009 Trastuzumab plus anastrozole versus anastrozole alone for the treatment of postmenopausal women with human epidermal growth factor receptor 2-positive, hormone receptor-positive metastatic breast cancer: results from the Randomized Phase III TAnDEM Study. Journal of Clinical Oncology 27 5529-5537. (doi:10.1200/JCO.2008.20.6847)

Kaufmann M, Jonat W, Hilfrich J, Eidtmann H, Gademann G \& Zuna I 2007 Improved overall survival in postmenopausal women with early breast cancer after anastrozole initiated after treatment with tamoxifen compared with continued tamoxifen: the ARNO 95 study. Journal of Clinical Oncology 25 2664-2670. (doi:10.1200/JCO.2006. 08.8054)

Kendall A, Dowsett M, Folkerd E \& Smith I 2006 Caution: vaginal estradiol appears to be contraindicated in postmenopausal women on adjuvant aromatase inhibitors. Annals of Oncology 17 584-587. (doi:10.1093/ annonc/mdj127)

Key TJ, Appleby PN, Reeves GK, Roddam A, Dorgan JF, Longcope C, Stanczyk FZ, Stephenson HE, Jr, Falk RT, Miller R et al. 2003 Body mass index, serum sex hormones, and breast cancer risk in postmenopausal women. Journal of the National Cancer Institute 95 1218-1226. (doi:10.1093/jnci/djg022)

Knowlden JM, Hutcheson IR, Jones HE, Madden T, Gee JM, Harper ME, Barrow D, Wakeling AE \& Nicholson RI 2003 Elevated levels of epidermal growth factor receptor/c-erbB2 heterodimers mediate an autocrine growth regulatory pathway in tamoxifen-resistant MCF-7 cells. Endocrinology 144 1032-1044. (doi:10.1210/ en.2002-220620)

Kofman S, Nagamani D, Buenger RF \& Taylor SG 1958 The use of prednisolone in the treatment of disseminated breast carcinoma. Cancer 11 226-232. (doi:10.1002/1097-0142(195801/02)11:1<226:: AID-CNCR2820110135>3.0.CO;2-S)

Kwan ML, Chen WY, Kroenke CH, Weltzien EK, Beasley JM, Nechuta SJ, Poole EM, Lu W, Holmes MD, Quesenberry CP, Jr et al. 2012 Prediagnosis body mass index and survival after breast cancer in the After Breast Cancer Pooling Project. Breast Cancer Research and Treatment 132 729-739. (doi:10.1007/s10549-011-1914-3)

van Landeghem AJJ, Poortman J, Nabuurs M \& Thijssen JHH 1985 Endogenous concentration and subcellular distribution of estrogens in normal and malignant breast tissue. Cancer Research 45 2900-2904. 
Lemon HM 1959 Prednisone therapy of advanced mammary cancer. Cancer 12 93-107. (doi:10.1002/1097-0142(195901/02)12:1<93::AID-CNCR $2820120115>3.0$. CO;2-I)

Luft R, Olivecrona H \& Sjögren B 1952 Hypophysectomy in man. Nordisk Medicin 14 351-354.

Lønning PE 2003 Study of suboptimum treatment response: lessons from breast cancer. Lancet Oncology 4 177-185. (doi:10.1016/S1470-2045 (03)01022-2)

Lønning PE 2004 Aromatase inhibitors in breast cancer. Endocrine-Related Cancer 11 179-189. (doi:10.1677/erc.0.0110179)

Lønning PE 2006 Comparing cost/utility of giving an aromatase inhibitor as monotherapy for 5 years versus sequential administration following 2-3 or 5 years of tamoxifen as adjuvant treatment for postmenopausal breast cancer. Annals of Oncology 17 217-225. (doi:10.1093/annonc/ mdj048)

Lønning PE \& Ekse D 1995 A sensitive assay for measurement of plasma estrone sulphate in patients on treatment with aromatase inhibitors. Journal of Steroid Biochemistry and Molecular Biology 55 409-412. (doi:10.1016/0960-0760(95)00180-8)

Lønning PE \& Geisler J 2008 Indications and limitations of third-gene ration aromatase inhibitors. Expert Opinion on Investigational Drugs $\mathbf{1 7}$ 723-739. (doi:10.1517/13543784.17.5.723)

Lønning PE \& Knappskog S 2013 Mapping genetic alterations causing chemoresistance in cancer; identifying the roads by tracking the drivers. Oncogene [in press]. (doi:10.1038/onc.2013.48)

Lønning PE \& Kvinnsland S 1988 Mechanisms of action of aminoglutethimide as endocrine therapy of breast cancer. Drugs 35 685-710. (doi:10.2165/00003495-198835060-00005)

Lønning PE, Kvinnsland S, Thorsen T \& Ueland PM 1987 Alterations in the metabolism of oestrogens during treatment with aminoglutethimide in breast cancer patients. Preliminary findings. Clinical Pharmacokinetics 13 393-406. (doi:10.2165/00003088-198713060-00004)

Lønning PE, Johannessen DC \& Thorsen T 1989a Alterations in the production rate and the metabolism of oestrone and oestrone sulphate in breast cancer patients treated with aminoglutethimide. British Journal of Cancer 60 107-111. (doi:10.1038/bjc.1989.231)

Lønning PE, Jacobs S, Jones A, Haynes B, Powles T \& Dowsett M 1991 The influence of CGS 16949A on peripheral aromatisation in breast cancer patients. British Journal of Cancer 63 789-793.

Lønning PE, Skulstad P, Sunde A \& Thorsen T 1989b Separation of urinary metabolites of radiolabelled estrogens in man by HPLC. Journal of Steroid Biochemistry 32 91-97. (doi:10.1016/0022-4731(89)90019-8)

Lønning PE, Dowsett M \& Powles TJ 1990 Postmenopausal estrogen synthesis and metabolism: alterations caused by aromatase inhibitors used for the treatment of breast cancer. Journal of Steroid Biochemistry 35 355-366. (doi:10.1016/0022-4731(90)90241-J)

Lønning PE, Bajetta E, Murray R, Tubiana-Hulin M, Eisenberg PD, Mickiewicz E, Celio L, Pitt P, Mita M, Aaronson NK et al. 2000 Activity of exemestane in metastatic breast cancer after failure of nonsteroidal aromatase inhibitors: a phase II trial. Journal of Clinical Oncology 18 2234-2244

Lønning PE, Taylor PD, Anker G, Iddon J, Wie L, Jørgensen LM, Mella O \& Howell A 2001 High-dose estrogen treatment in postmenopausal breast cancer patients heavily exposed to endocrine therapy. Breast Cancer Research and Treatment 67 111-116. (doi:10.1023/A:1010619225209)

Lønning PE, Geisler J, Krag LE, Erikstein B, Bremnes Y, Hagen AI, Schlichting E, Lien EA, Ofjord ES, Paolini J et al. 2005 Effects of exemestane administered for 2 years versus placebo on bone mineral density, bone biomarkers, and plasma lipids in patients with surgically resected early breast cancer. Journal of Clinical Oncology 23 5126-5137. (doi:10.1200/JCO.2005.07.097)

Lønning PE, Helle H, Duong NK, Ekse D, Aas T \& Geisler J 2009 Tissue estradiol is selectively elevated in receptor positive breast cancers while tumour estrone is reduced independent of receptor status. Journal of Steroid Biochemistry and Molecular Biology 117 31-41. (doi:10.1016/ j.jsbmb.2009.06.005)
Lønning PE, Haynes BP, Straume AH, Dunbier A, Helle H, Knappskog S \& Dowsett M 2011 Exploring breast cancer estrogen disposition: the basis for endocrine manipulation. Clinical Cancer Research 17 4948-4958. (doi:10.1158/1078-0432.CCR-11-0043)

MacNeill FA, Jones AL, Jacobs S, Lønning PE, Powles TJ \& Dowsett M 1992 The influence of aminoglutethimide and its analogue rogletimide on peripheral aromatisation in breast cancer. British Journal of Cancer $\mathbf{6 6}$ 692-697. (doi:10.1038/bjc.1992.339)

MacNeill FA, Jacobs S, Lønning PE, Powles TJ \& Dowsett M 1994 Combined treatment with 4-hydroxyandrostenedione and aminoglutethimide: effects on aromatase inhibition and oestrogen suppression. British Journal of Cancer 69 1171-1175. (doi:10.1038/bjc.1994.230)

MacNeill FA, Jacobs S, Dowsett M, Lonning PE \& Powles TJ 1995 The effects of oral 4-hydroxyandrostenedione on peripheral aromatisation in post-menopausal breast cancer patients. Cancer Chemotherapy and Pharmacology 36 249-254. (doi:10.1007/BF00685855)

Mamounas EP, Jeong JH, Wickerham DL, Smith RE, Ganz PA, Land SR, Eisen A, Fehrenbacher L, Farrar WB, Atkins JN et al. 2008 Benefit from exemestane as extended adjuvant therapy after 5 years of adjuvant tamoxifen: intention-to-treat analysis of the National Surgical Adjuvant Breast And Bowel Project B-33 trial. Journal of Clinical Oncology 26 1965-1971. (doi:10.1200/JCO.2007.14.0228)

Manson JE, Hsia J, Johnson KC, Rossouw JE, Assaf AR, Lasser NL, Trevisan M, Black HR, Heckbert SR, Detrano R et al. 2003 Estrogen plus progestin and the risk of coronary heart disease. New England Journal of Medicine 349 523-534. (doi:10.1056/NEJMoa030808)

Masamura S, Santner SJ, Heitjan DF \& Santen RJ 1995 Estrogen deprivation causes estradiol hypersensitivity in human breast cancer cells. Journal of Clinical Endocrinology and Metabolism 80 2918-2925. (doi:10.1210/jc. 80.10.2918)

Meldrum DR, Davidson BJ, Tataryn IV \& Judd HL 1981 Changes in circulating steroids with aging in postmenopausal women. Obstetrics and Gynecology 57 624-627.

Mendelson CR, Jiang B, Shelton JM, Richardson JA \& Hinshelwood MM 2005 Transcriptional regulation of aromatase in placenta and ovary. Journal of Steroid Biochemistry and Molecular Biology 95 25-33. (doi:10.1016/j.jsbmb.2005.04.016)

Mieog JSD, Morden JP, Bliss JM, Coombes RC, van de Velde CJH \& Comm IESS 2012 Carpal tunnel syndrome and musculoskeletal symptoms in postmenopausal women with early breast cancer treated with exemestane or tamoxifen after 2-3 years of tamoxifen: a retrospective analysis of the Intergroup Exemestane Study. Lancet Oncology 13 420-432. (doi:10.1016/S1470-2045(11)70328-X)

Miller WR, Telford J, Love C, Leonard RCF, Hillier S, Gundacker H, Smith H \& Dixon JM 1998 Effects of letrozole as primary medical therapy on in situ oestrogen synthesis and endogenous oestrogen levels within the breast. Breast 7 273-276. (doi:10.1016/S0960-9776(98)90095-9)

Miller WR, Larionov A, Renshaw L, Anderson TJ, Walker JR, Krause A, Sing T, Evans DB \& Dixon JM 2009 Gene expression profiles differentiating between breast cancers clinically responsive or resistant to letrozole. Journal of Clinical Oncology 27 1382-1387. (doi:10.1200/JCO.2008. 16.8849)

Miller TW, Balko JM \& Arteaga CL 2011 Phosphatidylinositol 3-kinase and antiestrogen resistance in breast cancer. Journal of Clinical Oncology 29 4452-4461. (doi:10.1200/JCO.2010.34.4879)

Morales L, Pans S, Paridaens R, Westhovens R, Timmerman D, Verhaeghe J, Wildiers H, Leunen K, Amant F, Berteloot P et al. 2007 Debilitating musculoskeletal pain and stiffness with letrozole and exemestane: associated tenosynovial changes on magnetic resonance imaging. Breast Cancer Research and Treatment 104 87-91. (doi:10.1007/s10549006-9394-6)

Morales L, Pans S, Verschueren K, Van Calster B, Paridaens R, Westhovens R, Timmerman D, De Smet L, Vergote I, Christiaens MR et al. 2008 Prospective study to assess short-term intra-articular and tenosynovial changes in the aromatase inhibitor-associated arthralgia syndrome.

Published by Bioscientifica Ltd. 
Journal of Clinical Oncology 26 3147-3152. (doi:10.1200/JCO.2007. 15.4005)

Morimoto LM, White E, Chen Z, Chlebowski RT, Hays J, Kuller L, Lopez AM, Manson J, Margolis KL, Muti PC et al. 2002 Obesity, body size, and risk of postmenopausal breast cancer: the Women's Health Initiative (United States). Cancer Causes \& Control 13 741-751. (doi:10.1023/ A:1020239211145)

Morishima A, Grumbach MM, Simpson ER, Fisher C \& Qin K 1995 Aromatase deficiency in male and female siblings caused by a novel mutation and the physiological role of estrogens. Journal of Clinical Endocrinology and Metabolism 80 3689-3698. (doi:10.1210/ jc.80.12.3689)

Motzer RJ, Escudier B, Oudard S, Hutson TE, Porta C, Bracarda S, Grünwald V, Thompson JA, Figlin RA, Hollaender N et al. 2010 Phase 3 trial of everolimus for metastatic renal cell carcinoma: final results and analysis of prognostic factors. Cancer 116 4256-4265. (doi:10.1002/ cncr.25219)

Mouridsen H, Gershanovich M, Sun Y, Pérez-Carrión R, Boni C, Monnier A, Apffelstaedt J, Smith R, Sleeboom HP, Jänicke F et al. 2001 Superior efficacy of letrozole versus tamoxifen as first-line therapy for postmenopausal women with advanced breast cancer: results of a phase III study of the International Letrozole Breast Cancer Group. Journal of Clinical Oncology 19 2596-2606.

Mouridsen H, Gershanovich M, Sun Y, Perez-Carrion R, Boni C, Monnier A, Apffelstaedt J, Smith R, Sleeboom HP, Jaenicke F et al. 2003 Phase III study of letrozole versus tamoxifen as first-line therapy of advanced breast cancer in postmenopausal women: analysis of survival and update of efficacy from the International Letrozole Breast Cancer Group. Journal of Clinical Oncology 21 2101-2109. (doi:10.1200/ JCO.2003.04.194)

Mouridsen H, Giobbie-Hurder A, Goldhirsch A, Thürlimann B, Paridaens R, Smith I, Mauriac L, Forbes J, Price KN, Regan MM et al. 2009 Letrozole therapy alone or in sequence with tamoxifen in women with breast cancer. New England Journal of Medicine 361 766-776. (doi:10.1056/ NEJMoa0810818)

Niraula S, Ocana A, Ennis M \& Goodwin PJ 2012 Body size and breast cancer prognosis in relation to hormone receptor and menopausal status: a meta-analysis. Breast Cancer Research and Treatment 134 769-781. (doi:10.1007/s10549-012-2073-x)

Nishihori T, Choi J, DiGiovanna MP, Thomson JG, Kohler PC, McGurn J \& Chung GG 2008 Carpal tunnel syndrome associated with the use of aromatase inhibitors in breast cancer. Clinical Breast Cancer 8 362-365. (doi:10.3816/CBC.2008.n.043)

Osborne CK, Pippen J, Jones SE, Parker LM, Ellis M, Come S, Gertler SZ, May JT, Burton G, Dimery I et al. 2002 Double-blind, randomized trial comparing the efficacy and tolerability of fulvestrant versus anastrozole in postmenopausal women with advanced breast cancer progressing on prior endocrine therapy: results of a North American trial. Journal of Clinical Oncology 20 3386-3395. (doi:10.1200/JCO.2002.10.058)

Partridge AH, LaFountain A, Mayer E, Taylor BS, Winer E \& Asnis-Alibozek A 2008 Adherence to initial adjuvant anastrozole therapy among women with early-stage breast cancer. Journal of Clinical Oncology 26 556-562. (doi:10.1200/JCO.2007.11.5451)

Penault-Llorca F, André F, Sagan C, Lacroix-Triki M, Denoux Y, Verriele V, Jacquemier J, Baranzelli MC, Bibeau F, Antoine M et al. 2009 Ki67 expression and docetaxel efficacy in patients with estrogen receptorpositive breast cancer. Journal of Clinical Oncology 27 2809-2815. (doi:10.1200/JCO.2008.18.2808)

Perez EA, Josse RG, Pritchard KI, Ingle JN, Martino S, Findlay BP, Shenkier TN, Tozer RG, Palmer MJ, Shepherd LE et al. 2006 Effect of letrozole versus placebo on bone mineral density in women with primary breast cancer completing 5 or more years of adjuvant tamoxifen: a companion study to NCICCTG MA.17. Journal of Clinical Oncology 24 3629-3635. (doi:10.1200/JCO.2005.05.4882)

Pfeiler G, Königsberg R, Fesl C, Mlineritsch B, Stoeger H, Singer CF, Pöstlberger S, Steger GG, Seifert M, Dubsky P et al. 2011 Impact of body mass index on the efficacy of endocrine therapy in premenopausal patients with breast cancer: an analysis of the prospective ABCSG-12 trial. Journal of Clinical Oncology 29 2653-2659. (doi:10.1200/ JCO.2010.33.2585)

Poortman J, Thijssen JHH \& Waard FD 1981 Plasma oestrone, oestradiol and androstenedione levels in post-menopausal women: relation to body weight and height. Maturitas 3 65-71. (doi:10.1016/ 0378-5122(81)90021-9)

Powles TJ, Hickish T, Kanis JA, Tidy A \& Ashley S 1996 Effect of tamoxifen on bone mineral density measured by dual-energy X-ray absorptiometry in healthy premenopausal and postmenopausal women. Journal of Clinical Oncology 14 78-84.

Protani M, Coory M \& Martin JH 2010 Effect of obesity on survival of women with breast cancer: systematic review and meta-analysis. Breast Cancer Research and Treatment 123 627-635. (doi:10.1007/ s10549-010-0990-0)

Rasmussen BB, Regan MM, Lykkesfeldt AE, Dell'Orto P, Del Curto B, Henriksen KL, Mastropasqua MG, Price KN, Méry E, Lacroix-Triki M et al. 2008 Adjuvant letrozole versus tamoxifen according to centrallyassessed ERBB2 status for postmenopausal women with endocrineresponsive early breast cancer: supplementary results from the BIG 1-98 randomised trial. Lancet Oncology 9 23-28. (doi:10.1016/S14702045(07)70386-8)

Regan MM, Neven P, Giobbie-Hurder A, Goldhirsch A, Ejlertsen B, Mauriac L, Forbes JF, Smith I, Láng I, Wardley A et al. 2011 Assessment of letrozole and tamoxifen alone and in sequence for postmenopausal women with steroid hormone receptor-positive breast cancer: the BIG 1-98 randomised clinical trial at 8.1 years median follow-up. Lancet Oncology 12 1101-1108. (doi:10.1016/S1470-2045(11)70270-4)

Robertson JF, Lindemann JP, Llombart-Cussac A, Rolski J, Feltl D, Dewar J, Emerson L, Dean A \& Ellis MJ 2012 Fulvestrant 500 mg versus anastrozole $1 \mathrm{mg}$ for the first-line treatment of advanced breast cancer: follow-up analysis from the randomized 'FIRST' study. Breast Cancer Research and Treatment 136 503-511. (doi:10.1007/s10549-012-2192-4)

Rochira V \& Carani C 2009 Aromatase deficiency in men: a clinical perspective. Nature Reviews. Endocrinology 5 559-568. (doi:10.1038/ nrendo.2009.176)

Sabnis G \& Brodie A 2011 Adaptive changes results in activation of alternate signaling pathways and resistance to aromatase inhibitor resistance. Molecular and Cellular Endocrinology 340 142-147. (doi:10.1016/j.mce.2010.09.005)

Samojlik E, Veldhuis JD, Wells SA \& Santen RJ 1980 Preservation of androgen secretion during estrogen suppression with aminoglutethimide in the treatment of metastatic breast carcinoma. Journal of Clinical Investigation 65 602-612. (doi:10.1172/JCI109705)

Santen RJ 1981 Suppression of estrogens with aminoglutethimide and hydrocortisone (medical adrenalectomy) as treatment of advanced breast carcinoma: a review. Breast Cancer Research 1 183-202. (doi:10.1007/BF01806259)

Santen RJ, Lipton A \& Kendall J 1974 Successful medical adrenalectomy with aminoglutethimide. Journal of the American Medical Association 230 1661-1665. (doi:10.1001/jama.1974.03240120029015)

Santen RJ, Santner S, Davis B, Veldhuis J, Samojlik E \& Ruby E 1978 Aminoglutethimide inhibits extraglandular estrogen production in postmenopausal women with breast carcinoma. Journal of Clinical Endocrinology and Metabolism 47 1257-1265. (doi:10.1210/jcem47-6-1257)

Santen RJ, Worgul TJ, Samojlik E, Interrante A, Boucher AE, Lipton A, Harvey HA, White DS, Smart E, Cox C et al. 1981 A randomized trial comparing surgical adrenalectomy with aminoglutethimide plus hydrocortisone in women with advanced breast cancer. New England Journal of Medicine 305 545-551. (doi:10.1056/ NEJM198109033051003)

Santen RJ, Song RX, Zhang Z, Kumar R, Jeng MH, Masamura A, Lawrence J, Jr, Berstein L \& Yue W 2005 Long-term estradiol deprivation in breast cancer cells up-regulates growth factor signaling and enhances 
estrogen sensitivity. Endocrine-Related Cancer 12 S61-S73. (doi:10.1677/ erc.1.01018)

Sasano H, Anderson TJ, Silverberg SG, Santen RJ, Conway M, Edwards DP, Krause A, Bhatnagar AS, Evans DB \& Miller WR 2005 The validation of new aromatase monoclonal antibodies for immunohistochemistry - a correlation with biochemical activities in 46 cases of breast cancer. Journal of Steroid Biochemistry and Molecular Biology 95 35-39. (doi:10.1016/j.jsbmb.2005.04.027)

Semiglazov V, Kletsel A, Semiglazov V, Zhiltzova E, Ivanov V, Dashyan G, Bozhok A, Melnikova O, Paltuev R \& Berstein L 2005 Exemestane (E) versus tamoxifen ( $\mathrm{T}$ ) as neoadjuvant endocrine therapy for postmenopausal women with ER+ breast cancer (T2N1-2, T3N0-1, T4NOM0). Journal of Clinical Oncology 23 (16 Suppl) 11s (Abstr 530).

Serra V, Scaltriti M, Prudkin L, Eichhorn PJ, Ibrahim YH, Chandarlapaty S, Markman B, Rodriguez O, Guzman M, Rodriguez S et al. 2011 PI3K inhibition results in enhanced HER signaling and acquired ERK dependency in HER2-overexpressing breast cancer. Oncogene 30 2547-2557. (doi:10.1038/onc.2010.626)

Sestak I, Sapunar F \& Cuzick J 2009 Aromatase inhibitor-induced carpal tunnel syndrome: results from the ATAC trial. Journal of Clinical Oncology 27 4961-4965. (doi:10.1200/JCO.2009.22.0236)

Sestak I, Distler W, Forbes JF, Dowsett M, Howell A \& Cuzick J 2010 Effect of body mass index on recurrences in tamoxifen and anastrozole treated women: an exploratory analysis from the ATAC trial. Journal of Clinical Oncology 28 3411-3415. (doi:10.1200/JCO.2009.27.2021)

Sluijmer AV, Heineman MA, Jong FHD \& Evers JLH 1995 Endocrine activity of the postmenopausal ovary: the effects of pituitary down-regulation and oophorectomy. Journal of Clinical Endocrinology and Metabolism $\mathbf{8 0}$ 2163-2167. (doi:10.1210/jc.80.7.2163)

Smith IE, Dowsett M, Ebbs SR, Dixon JM, Skene A, Blohmer JU, Ashley SE, Francis S, Boeddinghaus I \& Walsh G 2005 Neoadjuvant treatment of postmenopausal breast cancer with anastrozole, tamoxifen, or both in combination: the Immediate Preoperative Anastrozole, Tamoxifen, or Combined with Tamoxifen (IMPACT) multicenter double-blind randomized trial. Journal of Clinical Oncology 23 5108-5116. (doi:10.1200/JCO.2005.04.005)

Sørlie T, Perou CM, Tibshirani R, Aas T, Geisler S, Johnsen H, Hastie T, Eisen MB, van de Rijn M, Jeffrey SS et al. 2001 Gene expression patterns of breast carcinomas distinguish tumor subclasses with clinical implications. PNAS 98 10869-10874. (doi:10.1073/pnas.191367098)

Stewart HJ, Prescott RJ \& Forrest APM 2001 Scottish adjuvant tamoxifen trial: a randomized study updated to 15 years. Journal of the National Cancer Institute 93 456-462. (doi:10.1093/jnci/93.6.456)

Tormey DC, Gray R \& Falkson HC 1996 Postchemotherapy adjuvant tamoxifen therapy beyond five years in patients with lymph nodepositive breast cancer. Journal of the National Cancer Institute $\mathbf{8 8}$ 1828-1833. (doi:10.1093/jnci/88.24.1828)

Trial TW 1995 Effects of estrogen or estrogen/progestin regimens on heart disease risk factors in postmenopausal women. The postmenopausal estrogen/progestin interventions (PEPI) trial. Journal of the American Medical Association 273 199-208. (doi:10.1001/jama.1995. 03520270033028)
Untch M, Gelber RD, Jackisch C, Procter M, Baselga J, Bell R, Cameron D, Bari M, Smith I, Leyland-Jones B et al. 2008 Estimating the magnitude of trastuzumab effects within patient subgroups in the HERA trial. Annals of Oncology 19 1090-1096. (doi:10.1093/annonc/mdn005)

Vallabhaneni S, Nair BC, Cortez V, Challa R, Chakravarty D, Tekmal RR \& Vadlamudi RK 2011 Significance of ER-Src axis in hormonal therapy resistance. Breast Cancer Research and Treatment 130 377-385. (doi:10.1007/s10549-010-1312-2)

van de Velde CJ, Rea D, Seynaeve C, Putter H, Hasenburg A, Vannetzel JM, Paridaens R, Markopoulos C, Hozumi Y, Hille ET et al. 2011 Adjuvant tamoxifen and exemestane in early breast cancer (TEAM): a randomised phase 3 trial. Lancet 377 321-331. (doi:10.1016/ S0140-6736(10)62312-4)

Villarreal-Garza C, Cortes J, Andre F \& Verma S 2012 mTOR inhibitors in the management of hormone receptor-positive breast cancer: the latest evidence and future directions. Annals of Oncology 23 2526-2535. (doi:10.1093/annonc/mds075)

Wasan KM, Goss PE, Pritchard PH, Shepherd L, Palmer MJ, Liu S, Tu D, Ingle JN, Heath M, Deangelis D et al. 2005 The influence of letrozole on serum lipid concentrations in postmenopausal women with primary breast cancer who have completed 5 years of adjuvant tamoxifen (NCIC CTG MA.17L). Annals of Oncology 16 707-715. (doi:10.1093/annonc/ mdi158)

Weigel MT, Banerjee S, Arnedos M, Salter J, A'Hern R, Dowsett M \& Martin LA 2013 Enhanced expression of the PDGFR/Abl signaling pathway in aromatase inhibitor-resistant breast cancer. Annals of Oncology 24 126-133. (doi:10.1093/annonc/mds240)

Weigelt B, Warne PH \& Downward J 2011 PIK3CA mutation, but not PTEN loss of function, determines the sensitivity of breast cancer cells to mTOR inhibitory drugs. Oncogene 30 3222-3233. (doi:10.1038/onc.2011.42)

Wills S, Ravipati A, Venuturumilli P, Kresge C, Folkerd E, Dowsett M, Hayes DF \& Decker DA 2012 Effects of vaginal estrogens on serum estradiol levels in postmenopausal breast cancer survivors and women at risk of breast cancer taking an aromatase inhibitor or a selective estrogen receptor modulator. Journal of Oncology Practice 8 144-148. (doi:10.1200/JOP.2011.000352)

Wolff AC, Lazar AA, Bondarenko I, Garin AM, Brincat S, Chow L, Sun Y, Neskovic-Konstantinovic Z, Guimaraes RC, Fumoleau P et al. 2013 Randomized phase III placebo-controlled trial of letrozole plus oral temsirolimus as first-line endocrine therapy in postmenopausal women with locally advanced or metastatic breast cancer. Journal of Clinical Oncology 31 195-202. (doi:10.1200/JCO.2011.38.3331)

Yao JC, Lombard-Bohas C, Baudin E, Kvols LK, Rougier P, Ruszniewski P, Hoosen S, St Peter J, Haas T, Lebwohl D et al. 2010 Daily oral everolimus activity in patients with metastatic pancreatic neuroendocrine tumors after failure of cytotoxic chemotherapy: a phase II trial. Journal of Clinical Oncology 28 69-76. (doi:10.1200/JCO.2009.24.2669)

Zhou J, Suzuki T, Kovacic A, Saito R, Miki Y, Ishida T, Moriya T, Simpson ER, Sasano H \& Clyne CD 2005 Interactions between prostaglandin E-2, liver receptor homologue-1, and aromatase in breast cancer. Cancer Research 65 657-663.

Received in final form 19 April 2013

Accepted 23 April 2013

Made available online as an Accepted Preprint

26 April 2013 http://erc.endocrinology-journals.org

DOI: 10.1530/ERC-13-0099
(C) 2013 The authors Printed in Great Britain
Published by Bioscientifica Ltd. 